\title{
Autonomy in Budgeting Decisions of Local \\ Government Union Councils: A Study of Bangladesh
}

\author{
Mohammad Rafiqul Islam Talukdar \\ GSPA-NIDA, Bangkok, Thailand \\ E-mail: rafiqul.talukdar@gmail.com
}

Received: Dec. 16, 2018 Accepted: May 10, 2019 Online published: May 12, 2019

doi:10.5296/jpag.v9i2.14773 URL: https://doi.org/10.5296/jpag.v9i2.14773

\begin{abstract}
Considering the critical influencing phenomena, the study explores the causal mechanism of influences, as well as how such process works that lead to shape the dominant implications of influences on local government Union Councils' budgetary autonomy, leading to the impact on their local governance.

The research reveals the fact that the effects of the influencing phenomena on the budgetary autonomy of Union Councils in Bangladesh are evident with varying degrees and dimensions, but the influences do not always collide with the budgetary autonomy of Union Councils there. The indicator-based empirical analysis reveals that the magnitude of influences is almost double than that of the budgetary autonomy of Union Councils in Bangladesh. Thus, the autonomy of Union Councils in their budgeting decisions is a concern in the study of decentralization and local governance in Bangladesh.

Originality and significance:

The research contributed in the literature stream of public administration, specifically in decentralization, local government finance as well as budgeting, and in local governance studies. The study findings to some extent substantiated the rationality of conditional national government transfers to the sub-national governments in Bangladesh. Beyond the general theoretical and practical significance of the study, its findings led to inviting a fundamental debate on the national-local tax base system and appreciated the fact that central hindrance towards effective functioning of the local government Union Councils in Bangladesh is the crisis of ownership and competence of UP representatives.
\end{abstract}

Keywords: Bangladesh, budgetary-autonomy, budgeting-decision, budget-theory, union council, local government 


\section{Introduction}

Understanding the level of budgetary autonomy of local government Union Councils in Bangladesh requires predominantly considering the autonomy of the same in relation to the resources needed to perform the responsibilities assigned to these councils. Simple observations support that demands for public goods and services are increasingly exceeding the supply at the local governments in Bangladesh and elsewhere, particularly in developing countries. Furthermore, the research of Devas (1988) and Talukdar (2013) reveals the fact that the revenue assignments of local governments in most developing countries including Bangladesh are often very poorly designed and very limited.

The limitation of these revenue assignments occurs simply because in most countries, national governments or central governments have undertaken the main revenue sources, including the mainstream local base revenues, for themselves. This appropriation causes the allocation of national funds to local governments to overcome the mismatch between the increased responsibilities and limited resources available at the grass root levels of a government (Devas, 1988). Thus, the local government budgeting becomes a major process of gaining public resources through intergovernmental transfers and by mobilizing local resources, as well as efficiently planning and strategically allocating the resources along with controlling fiscal management (Talukdar, 2019).

Such a process might require a continuum of decision-making theories that fundamentally invites tradeoffs between the political/incremental decision-making and systematically analyzed rational choice-making. But in practice, in many developing countries as in Bangladesh, national government allocations to local governments (i.e. intergovernmental transfers) follow mostly the incremental model and the slightly rational choice model, while on the part of the local government, allocation of its probable aggregate resources to the expenditure responsibilities is based on the translation of a five-year strategic development plan into prioritized yearly planning with a blended approach of systematic and political analysis.

Therefore, understanding the autonomy of Union Councils/Parishads (UPs) in their budgetary decision-making process entails a combination of political psychology, applied economics and public management issues (i.e. decentralization, local government finance and local governance, and organization as well as budgeting theories). Considering the critical influencing phenomena and the context-specific relative influences of the issues on the UP-budgetary process (as documented in Talukdar, 2019), the current article explores the causal mechanism of influences, as well as how such process works that lead to shape the dominant implications of influences on local government Union Councils' budgetary autonomy, leading to the impact on their local governance.

The article includes discussions on the context (i.e. decentralization, local governance, local government structure, local government finance and local government budgetary process in Bangladesh), concepts (i.e. influence and autonomy, budgeting and decision making, and political psychology and applied economics), theories (i.e. organization and budget theories), research methodology (i.e. research method and approaches, sampling and research questions, 
and data analysis mapping), research results ( i.e. findings and contributions), and recommendations and conclusion.

\section{The Context}

\subsection{Decentralization and Local Governance in Bangladesh}

Simply subnational decentralization refers to the 'devolution' that is the increased reliance upon the local government institutions, with some degree of political autonomy (USAID, 2000). While, academically, devolution does not necessarily mean democratic decentralization or institution of democracy in local governance, there is an inclination to equate the two (Oxhorn, 2004). Democratic decentralization goes further than the devolution does in terms of autonomy, responsibility and accountability of the local authority, and participation, opportunity and emancipation of the people. Two interlinked and inevitable components of this latest form of decentralization are structural decentralization and institutional democratization (Talukdar, 2013).

Structural decentralization refers to devolution in the organization and relationship of government units, in relation to one another including a shift of production and provision functions to more localized government units (Hicks and Kaminski, 1995; Rainey, 1997).

Basically, structural decentralization alerts the balance of exercising the power among levels of government favoring localized levels of government; even to some extent this component allows local people's representatives to govern the local government, but values associated with legacy do not always change until it goes with institutional democratization (Talukdar, 2013 and 2014).

Institutional democratization refers to this shift in values, rules, skills, and interactions, favoring transparency, equity, responsiveness, accountability, and other traditional democratic values (Hodgson, 2006; McGill, 1997; OECD, 1996).

Evidence of 'institutional democratization' can be found through functioning monitoring and accountability mechanisms, and by ensuring the efficient integration of citizenry input into public decision-making process (Coston, 1998; Klingner, 1996).

A fully-fledged democratic decentralization not only creates environment for wider participation and social inclusiveness, as well as for citizens to demand accountability of local authority, but also generates a sense of transparency and accountability of the political system and governance (Talukdar, 2013 and 2014).

It is gratifying to see the fact that researchers are recognizing the decentralization that takes place within a political context, and therefore notions of decentralization evolve differently in each country (Smoke, 2003); yet, the requirements of decentralization set unvaryingly high standards (Dauda,2006).

Although Bangladesh is stepping ahead to the latest form of subnational decentralization democratic decentralization, there are lots of challenges ahead in this connection, particularly concerning the fiscal and budgetary autonomy of the local government institutes, and so is 
true in the context of local government Union Councils.

The contemporary local governance in Bangladesh focuses on how the current paradigm of decentralization can open avenues for the development of democratic local governance. To get the proper outcome of this latest form of decentralization (i.e. democratic decentralization), local government must be responsive to citizen needs and gain the authority, resources and skills needed to be operative and accountable (Talukdar, 2013).

\subsection{Local Government and Its Structure in Bangladesh}

Despite a long heritage of local government in Bangladesh, success of decentralization is mixed here, and it has brought a little pro-people innovation. There are three distinct reasons for that: first, a weak inter-governmental relationship - poor status of balance of power between central and local governments, and poorly set inherent links between and among local government institutions; second, disproportionate magnitude of administrative, political, and fiscal decentralization; and third, the frequent changes of the system.

Local government reforms have evolved in Bangladesh very strikingly according to the predilection of the ruling elites (Khan and Hussain, 2001; Westergaard, 2000). Previous research findings (Talukdar, 2009, 2014) support that functions, finance and functionaries are vital to making this decentralization process successful, while a trend of imbalance among these elements is always strongly evident at local government institutions in Bangladesh. The study (Talukdar, 2014) also supports that absence of an aggregate local governance policy in Bangladesh is deepening the problems and their causes stated above. Talukdar (2014) suggests that unless Bangladesh makes an aggregate local governance policy, it will not have a vision and road map for development of its local governance.

Aminuzzaman (2010), further argues that local government has been constantly identified as a key strategic segment for improving governance and development in Bangladesh. A 2001 study of Khan observes that one of the vital concerns in relation to decentralization in Bangladesh is greater autonomy of the local state (Khan, 2001). The principal premise of this research is that a greater autonomy of the local state helps improve the effectiveness of decentralization. The main research concern of this study is the exploration of the causal mechanism and dominant implications of influences on local government Union Councils' budgetary autonomy. Table 1 shows the local government institutions in Bangladesh at a glance.

Table 1. Local Government Institutions in Bangladesh

\begin{tabular}{lll}
\hline $\begin{array}{l}\text { Urban } \\
\text { Local Government }\end{array}$ & $\begin{array}{l}\text { Rural } \\
\text { Local Government }\end{array}$ & $\begin{array}{l}\text { Special } \\
\text { Local Government }\end{array}$ \\
\hline City Corporations (11) & Zilla Parishads (61) & Chittagong Hill Regional Council (1) \\
\hline Municipalities (323) & Upazila Parishads (490) & Chittagong Hill District Councils (3) \\
\hline Cantonment Boards (30) & Union Councils/Parishads (4553) & $\begin{array}{l}\text { Traditional Raja (3) and Mouza Based } \\
\text { Headman-Karbari (472) }\end{array}$ \\
\hline
\end{tabular}

Source: Talukdar, 2013 


\section{Macrothink}

As shown in Table 1, there are a total of 11 City Corporations, 323 Municipalities (out of which 3 are in the hill area), 61 Zila Parishad/District Councils, 490 Upazila Parishads/Sub-districts (out of which 25 are in the hill area), 4553 Union Parishads (out of which 118 are in the hill area), 1 Hill Regional Council, 3 Hill District Councils, 3 Traditional Raja, and 472 Headman Karbari. Noteworthy is the fact that Cantonment Board is not being considered as the local government unit in a purely academic sense.

Below shows the structure of the Union Council as the Local Government Institute (LGI) in Bangladesh.

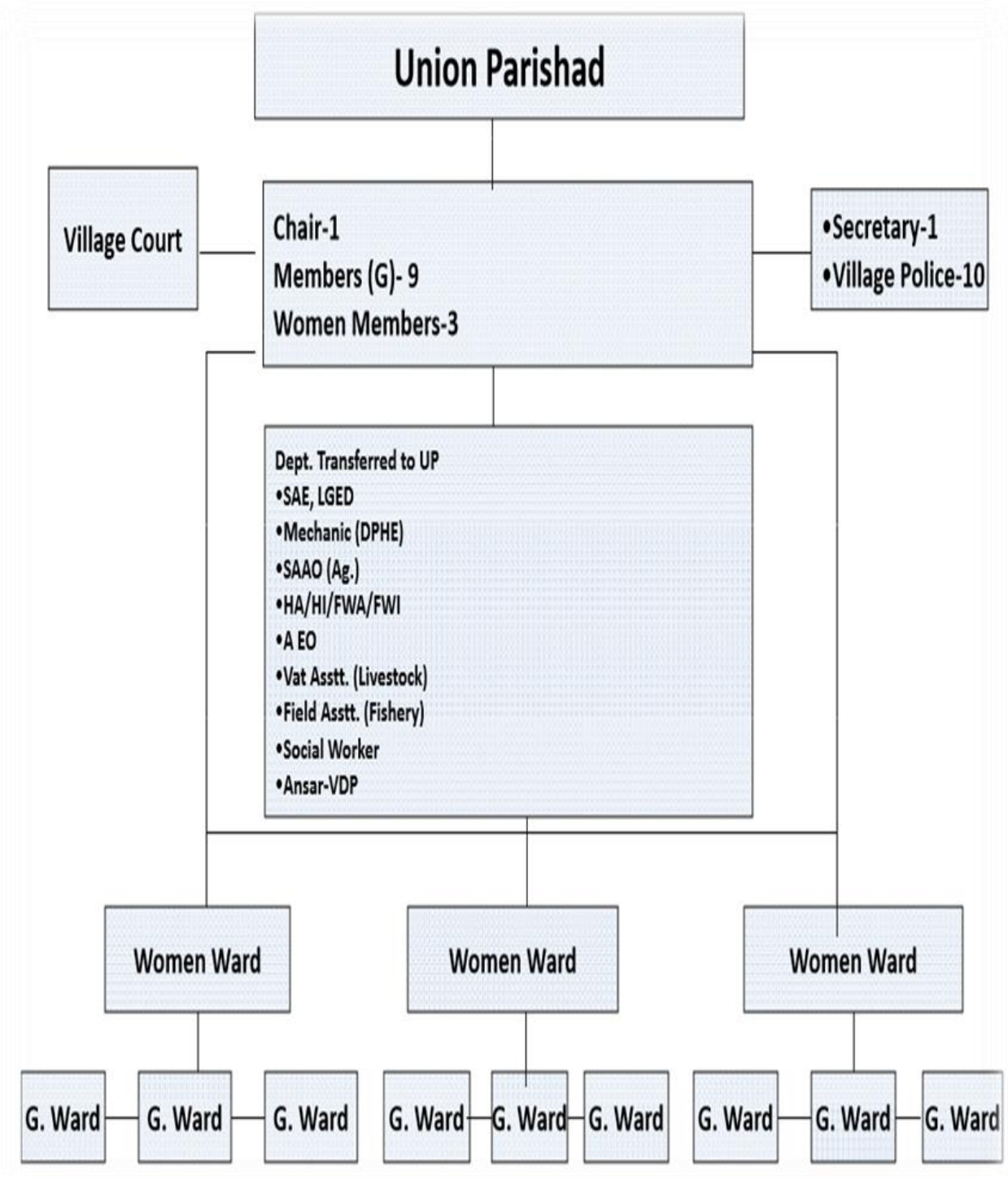

Figure 1. Structure of the Union Council in Bangladesh

Source: Ahmed, 2014 
Table 2 below shows the feature of the local government Union Council in Bangladesh.

Table 2. Feature of the Union Council in Bangladesh

\begin{tabular}{|c|c|c|c|c|c|c|}
\hline $\begin{array}{r}\text { Level } \\
\& \\
\text { Quantity }\end{array}$ & $\begin{array}{l}\text { Area } \\
\text { \&Population } \\
\text { Per Unit }\end{array}$ & $\begin{array}{l}\text { Legal } \\
\text { Basis }\end{array}$ & $\begin{array}{l}\text { Headed } \\
\text { By }\end{array}$ & Composition & $\begin{array}{l}\text { Revenue } \\
\text { Authority }\end{array}$ & $\begin{array}{l}\text { Functional } \\
\text { Observation }\end{array}$ \\
\hline $\begin{array}{l}4553 \\
\text { Lowest } \\
\text { unit- } \\
\text { Exclusive } \\
\text { ly Rural }\end{array}$ & $\begin{array}{l}26.18(\mathrm{~km}) 2 \\
27000\end{array}$ & $\begin{array}{l}\text { The } \\
\text { Local } \\
\text { Governm } \\
\text { ent } \\
\text { (Union } \\
\text { Parishad) } \\
\text { Act, } \\
2009 \\
\text { (Act No. } \\
61 \text { of } \\
2009 \text { ) }\end{array}$ & $\begin{array}{l}\text { Elected } \\
\text { Chairman }\end{array}$ & $\begin{array}{l}\text { A Union } \\
\text { Parishad } \\
\text { consists of } 1 \\
\text { elected } \\
\text { Chairman and } \\
12 \text { members } \\
\text { including } 3 \\
\text { members } \\
\text { exclusively } \\
\text { reserved for } \\
\text { women. There } \\
\text { is also a } \\
\text { secretary to the } \\
\text { parishad. }\end{array}$ & $\begin{array}{l}\text { Limited } \\
\text { revenue } \\
\text { authority } \\
\text { and scope } \\
\text { but does not } \\
\text { have } \\
\text { sub-national } \\
\text { borrowing } \\
\text { authority. }\end{array}$ & $\begin{array}{l}\text { Participatory } \\
\text { planning, } \\
\text { budgeting and } \\
\text { implementation, } \\
\text { and service } \\
\text { monitoring } \\
\text { powers, but } \\
\text { limited staffing } \\
\text { capacity. }\end{array}$ \\
\hline
\end{tabular}

Source: Talukdar, 2013

\subsection{Local Government Finance and Budgetary Process in Bangladesh}

A World Bank working paper on local government budgeting recognizes the fact that decentralization reforms in many developing countries are fostering changes in governance structures that are reshaping the relationship between local governments and citizens. The paper points out that the success of such decentralization reforms depends largely on the existence of sound public financial systems both at the central and local levels. Also, the role of budgeting is appreciated as a central tool in such reform efforts. It has also identified the problems or limitations that might hinder successful local government budget development and implementation (Schaeffer and Yilmaz, 2008).

The editorial preface of a 1988 UNCRD book identifies the fact that in many developing countries the core development problem at the sub-national level is the inadequate fiscal resource base of local and regional governments (Prantilla, 1988). Considering the bounded legal-rational framework, generally the same might be true in the case of Bangladesh, particularly at the Union Council level.

Interestingly, anecdotes and priori-observations support that in the case of study geographical area, there are plentiful local natural resources, while the problem is associated with the legal access barriers of local governments to those properties. Certainly, national-local tax base system of the country is a fundamental issue. In the case of Bangladesh, the nation's de jure practice is that tax from the major local sources goes to national government and the same tax shall then be distributed at the national and sub-national level. Therefore, the local 
government tax net as well as base seems to be very poor in Bangladesh.

Thoni (1992) deals with the lens of 'political economy' instead of purely 'economic' approach to tackle the local expenditure and frame the tax base. When it comes to the lens of political economy, it allows the analysis of the relationship between the institutional arrangements and the economic policies of the state and local authorities. In his context, analyzing the 'politics of local governments' means studying the decision-making processes of the local governments in relation to the politics of these local governments as well as the national government.

Regardless the reason of the problem, there is always a strong mismatch between the resources legitimately at hand of decentralized local governments in Bangladesh, like Union Councils, and the responsibilities assigned to them. Thus, Devas (1988) fairly identifies that the main reason for allocating national funds to local governments relates to the mismatch between the resources available to decentralized agencies and the responsibilities assigned to local governments.

Importantly, the core process of budget preparation supposes to include setting up the fiscal targets given the compatible expenditure assignments and strategic allocation of resources and mechanism for ensuring aggregate expenditure control, operational efficiency and competitive advantages. Following the theoretical base, government policies as well as rules-regulations, and analyzing the trade-offs as well as making prioritization from alternative options, setting up the most cost-effective variants supposes to be a sensible way for ensuring competitive advantage of the budgeting process.

Understanding the process by which local government Union Councils/Parishads (UPs) in Bangladesh make budgeting decisions is important to explain the decisions they make in this regard. Figure 2 shows the budget life cycle of Union Councils in Bangladesh.

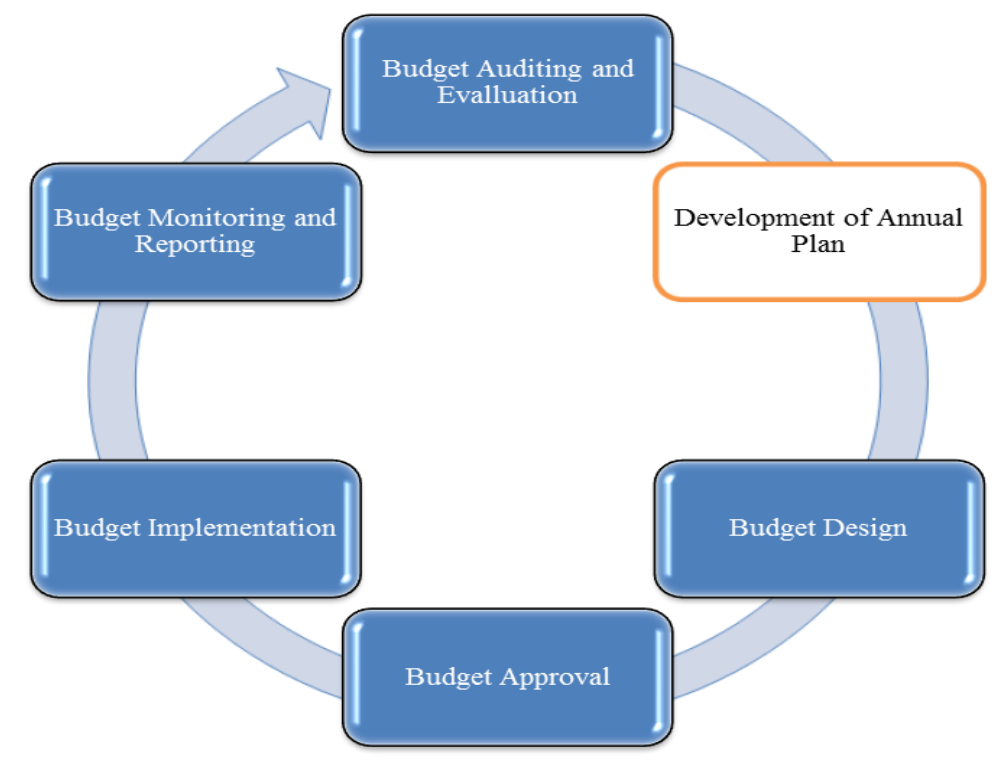

Figure 2. Budget life cycle of local government Union Councils

Source: Adapted from the Local Governance Programme Sharique's training document 


\section{Ml Macrothink}

Journal of Public Administration and Governance

ISSN 2161-7104

2019, Vol. 9, No. 2

Budgeting process of a UP in Bangladesh supposes to start tailoring an annual development plan by a planning committee, based on the strategic five-year plan of the UP. It requires reviewing the strategic five-year plan to sketch a draft plan, initiating ward ${ }^{1}$ level discussions and placing ward level findings and demands to the UP-standing committees for their screening, making recommendations, and then framing the plan. ${ }^{2}$

Then usually the secretary along with the planning committee of a UP outlines the budget by subsuming the assessment of assets and revenues including grants, and assuming liabilities and expenditures based on the plan and office memos as well as documents, followed by placing the same to the Union Council Coordination Committee (UDCC) for its comments and conducting an open budget meeting by the UP Chair in the presence of hundreds of local citizens at the UP level. Usually the Chair of a UP presents the draft budget to the open budget meeting for public review and feedback. ${ }^{3}$

Following public disclosure and assessment, the Union Council revisits the budget and endorses it with or without making changes. UP then submits it the delegated government authorities, i.e. Upazila Nirbahi Officer (UNO), Deputy Director of Local Government (DDLG) and Deputy Secretary (DC). Local Government Division (LGD) of the Ministry of Local Government, Rural Development and Cooperatives (MLGRD\&C) then allocates the actual amount of grants and keeps the UPs informed through official letters. Thus, a UP again revisits the actual fund situation, revises and adjusts the budget, and re-endorses it. Next stage is the implementation followed by monitoring and reporting, and audit and evaluation of the budget. $^{4}$

\section{Concepts}

\subsection{Influence and Autonomy}

The term 'influence' refers here to the phenomenal capacity of an aspect to affect the budgeting decision or behavior of local government Union Councils. It denotes the capacity of influencer or the influencing aspect (i.e. persons or things) to tailor a compelling force on the action, choice and behavior relating to the budgeting decision of Union Councils in Bangladesh.

The concept of 'autonomy' simply makes sense here as the combination of degree of freedom, discretion of legal authority and level of rational power regarding the actions and decisions of the Union Councils in Bangladesh, particularly the budgeting decisions that they take in this context. Autonomy is an important property for self-government.

In this research, 'freedom' refers to Swift's view regarding effective freedom and freedom as autonomy (Swift, 2014: 66), as well as Kant's view that freedom consists in acting morally (Swift, 2014: 69). Also, 'legal authority', in this study, entails formal authority provided in the concerned laws/acts, policy documents, rules, and regulations whereas

\footnotetext{
${ }^{1}$ There are nine subunits of a UP, each of which is known as a Ward.

2 Based on the Local Governance Programme Sharique's UP budgeting training documents

3 ibid

4 ibid
} 
rational power implies the ability to exercise the given freedom and authority in a sensible manner.

\subsection{Budgeting and Decision Making}

According to Henley 'budgeting' is a process of measuring plans and converting resources into financial values.

Budgeting is a process of measuring and converting plans for the use of real (i.e. physical) resources into financial values. It is the classic problem of how to add together quantities of apples and oranges into a meaningful economic measurement, the only practical way for everyday use is to express their economic values in terms of monetary costs and revenues. Through the process of budgeting the finance function provides the essential link between management planning and management control (Henley, 1992).

'Decision-making' is simply regarded as the reasoning process resulting in the selection of a choice or deciding without choice options, or a course of action among several alternative possibilities. Several factors, including experience (Jullisson., Karlsson and Garling, 2005), cognitive biases (Stanovich and West, 2008), age and individual differences (Bruin.; Parker and Fischhoff, 2007), belief in personal relevance (Acevedo and Krueger, 2004), and an escalation of commitment (Dietrich, 2010) influence individuals in their decision-making process. Individual level decision making is an area of research under the domain of cognitive psychology.

\subsection{Political Psychology and Applied Economics}

Political psychology is an interdisciplinary academic field related to describing how individuals as public institutional representatives make their decisions relating to budgeting considering the exogenous political and cognitive psychological factors, and thus it is dedicated to understanding politics, politicians and political behavior from a psychological perspective. According to Cottam et al. (2010), political psychology intends to understand inter-dependent relationships between individuals and contexts that are influenced by beliefs, perception, cognition, motivation, socialization, information processing, learning strategies and attitude formation.

The way Henley (1992) defines budgeting, it strongly reveals the concept of 'applied economics'. Within the study of public budgetary decision making, for instance, local government budgeting decision making invites applied economics in terms of allocating public resources, in addition to the political psychological process being practiced in public budgetary decisions as discussed above.

\section{Theoretical Relevance}

\subsection{Organization and Budgeting Theories}

Prior to the late 1960s, most organizational analysis involved a focus on the internal workings of organizations, except the works of the old institutional school, such as Selznick (1949), Gouldner (1954) and Zald (1970) that emphasized the organizations' ties with their 
environments on a limited scale.

Since the late 1960s, and throughout the 1970s and onward, mainstream organizational theories concerning external environment, for example, structural contingency, resource dependence, new institutional theory, population ecology, and inter-organizational relationships, evolved.

A dominant approach in the late 1960s, influenced by Thompson (1967) and Lawrence and Lorsch, (1967), known as the structural contingency theory, was first clearly concerned with organizations' interactions with their environments.

Then in the 1970s and onward, organizations' relations with their environments turn out to be a major focus of study. Such works included Williamson's (1975) book on 'transaction-cost economics', Hannan and Freeman's (1977) article on 'the population ecology of organizations', and Pfeffer and Salancik's (1978) book on 'organization's resource dependence on external environments', and the new institutional theory, led by Meyer and Rowan's (1977) article on 'organizations as myth and ceremony', and further influenced by DiMaggio and Powell's (1983) essay on 'institutional isomorphism'.

The inter-organizational relationships theory also grew simultaneously and continued to evolve until the early $21^{\text {st }}$ century. Interestingly, inter-organizational relationships theory was mainly influenced by the transaction costs economics theory (Williamson, 1975), the agency theory (Eisenhardt, 1989) and the resource dependence theory (Pfeffer and Salancik, 1978, 2003). The inter-organizational relationships were further termed as 'partnership', 'alliance', 'collaboration', 'network', and 'inter-organizational relations' (Baker et al., 2011).

Notably, public budgeting is the linking process of performance with the amount of resources required to accomplish those tasks, and most of the budgeting work is technical as well as managerial in nature, but the public budgeting is also necessarily and appropriately a political process (Rubin, 2014).

According to Menifield (2013), budget comes in three forms: i) Line item, ii) Program, and iii) Performance. There are also budgeting techniques: a) Zero-based budgeting, and b) Incremental budgeting. In the case of zero-based budgeting, it starts from zero or beginning, and thus each unit submitting a budget must justify all their budget requests from beginning to end, while in incremental budgeting, an agency may also use an incremental approach to budgeting where it simply adds or subtracts from the previous year's spending. Importantly, national governments may require agencies or local governments to submit a certain type of budget that they prefer (Axelrod, 1995; Gianakis and McCue, 1999; Menifield, 2013; Smith and Lynch, 2004; Thurmaier and Willoughby, 2001).

Budgeting theories, especially Charles E. Lindblom's incrementalism in public decision making and Aaron Wildavsky's budgetary incrementalism, Irene Rubin's review of descriptive and normative budgetary theories and historical review of the budgetary reform process, and Wehner's critical analysis to Wildavsky's budgetary theory are likely to help much in analyzing the budgetary process and decisions with regards to understanding the ownership as well as accountability and the magnitude of budgetary autonomy of local 
government Union Councils in Bangladesh.

Wehner (2015) analyses Aaron Wildavsky's seminal work, The Politics of the Budgetary Process, published in 1964. Wehner considers Wildavsky's contribution as a classic one in public administration as the book used a simple yet fundamental theoretical framework for analyzing budgetary decisions that took an in-depth look at the norms and rules of budgeting in the United States and the stable patterns of interaction between the various actors involved. Wehner, however, discusses the challenges to Wildavsky's theory of budgetary incrementalism that arose mainly in the context of economic and fiscal crisis.

Rubin (1990) observes the fact that the incrementalistic model argued that no major changes were made in the budgets from year to year and hence few choices of policy consequence were being made in the context of the budget. It, however, had lack of comparison between alternatives for spending, and prevented many budgeters from seeing the changing budget reality and theorizing about it.

Notably incrementalism was originally built as a theory of public policy making in the 1950s by the American political scientist Charles E. Lindblom. In 1959, Lindblom wrote an easy The Science of Muddling Through, to help policymakers understand why they needed to consider a middle way between the 'rational actor model' and 'bounded rationality' to avoid making changes before they really get engaged to the complexity and evolving rationality of the issue.

'Incrementalism', a dominant theory in public budgeting, is intended not only as a descriptive theory but also as a normative one. In the purely normative lens of public budgeting theory, public accountability, citizenry involvement and central-local partnership, transparency, cost-effectiveness, and quality service delivery are central to the literature. Rubin (1990) observes that these could only be achieved by improving the quality of budget information and publicizing that information to allow increased access of the people to this information.

Rubin (1990) further points out that both the public and legislature should understand the government's activities and achievements and spending in those same areas. Thus, cost accounting, program budgeting implications and detailed performance budgets based on unit costs get reform attention, and such approach does not limit new services to be included in the budget considering the changing reality of the budget. Such reformers also emphasize the role of planning in the budget and argue that budgets must contain a work plan and provide funding for future as well as current needs.

\subsection{How These Theories Relevant to This Research}

Organizational theories, particularly resource dependence, inter-organizational relationship and one element of the new institutional theory i.e. coercive isomorphism are closely linked to understanding the organizational context of influence and autonomy of the local government Union Councils in Bangladesh.

Budgeting theories, especially Charles E. Lindblom's incrementalism in public decision making and Aaron Wildavsky's budgetary incrementalism, Irene Rubin's review of 
descriptive and normative budgetary theories, as well as the historical review of the budgetary reform process, and Wehner's critical analysis to Wildavsky's budgetary theory help much in analyzing the budgetary process and decisions with regards to understanding the ownership as well as accountability and the magnitude of budgetary autonomy of local government Union Councils in Bangladesh.

\section{Research Methodology}

\subsection{Research Method and Approaches}

Examining the autonomy in budgeting decisions of Union Councils, the lowest unit of rural local governments in Bangladesh, invites rigorous qualitative research design. The rationality of undertaking qualitative approach here is to understand how the causes of the problem (i.e. influences) govern the influence process in relation to social phenomena, experience, reality, practice, organizational context and political culture, and why and how they affect budgetary autonomy of UPs leading to the effects in their local governance.

Thus, the research employs qualitative research method with a few case studies on criteria based purposively selected UPs of Sunamganj district in Bangladesh. Sunamganj, one of the 64 districts in Bangladesh, is chosen given the researcher's ${ }^{5}$ personal orientation with the context and Local Governance Programme Sharique's ${ }^{6}$ interventions as well as experience in the area. Also, as there are lots of homogeneity of UPs at all districts in Bangladesh, countrywide generalizing the contribution, grounded on the research findings, seems to be appropriate here. However, to avoid any academic challenge, the practical contribution of this research generalizes only within the study district where the research operates, while the theoretical contribution, following the grounded theory building approach and certain assumptions of the context, is subject to generalize both country-wide and globally.

The data collection techniques of the research include 'in-depth interviews' of chairpersons and secretaries of the unit of analysis, 'focus group discussions' of members of UPs, 'document reviews' of UPs, media review, and 'researcher's comprehensive observations. This study further employs an emergent framework. The emergent approach allows here for understanding the concerns of research questions from the perspective of the elected representatives (i.e. chairmen and members of UPs) and secretaries to the UPs, that is, the research participants' perceptions and concerns as they emerge, rather than their voice being refocused. Such emergent approach is going to follow the lens of some existing theories. The study draws on the grounded-theory approach to data collection, analysis, and is closely linked to data and the context.

There are some key differences between this approach and the full grounded-theory method defined by Glaser $(1978,1992)$. Although the main purpose of the research is to build a detailed thematic description of budgetary autonomy of local government UPs in Bangladesh, it does not limit the research to contribute in theory based on the inductive as well as

\footnotetext{
${ }^{5}$ Researcher's village home is at Sunamganj District in Bangladesh. Also, he was the programme board member of Local Governce Programme Sharique.

${ }^{6}$ Sharique was a local governance project, operated at Sunamganj, Rashahaji, Chapai Nawabganj and Khulna Districts at Union Council/Parishad level. The project closed in June 2017.
} 
grounded theory building approach.

The research limits its scope to the budget preparation and council's approval stage, and to some extent to the extended discourse of approval stage. The thesis does not encounter the other two stages of the budget cycle - budget execution, and the audit and evaluation phases. Also, the thesis focuses on the yearly budgeting decision-making process of the Union Councils, not on the five-year planning or any other type of planning.

\subsection{Time, Sampling and Research Questions}

The research collected the field data during the period of January-March 2018. The sample size of this qualitative study is limited to six case studies on criteria based purposively selected Union Councils of Sunamganj district in Bangladesh. Table 3 below shows the list of sample UPs at a glance.

Table 3. List of Sample Union Councils

\begin{tabular}{|c|c|}
\hline \multicolumn{2}{|c|}{ SUNAMGANJ DISTRICT/ZILA } \\
\hline Dharmapasha Subdistrict/Upazila & Jamalganj Subdistrict/Upazila \\
\hline - Joysree Union Council & - Jamalganj Sadar Union Council \\
\hline - Uttar Sukhair Rajapur Union Council & - Bhimkhali Union Council \\
\hline - Madhanagar Union Council & - Fenarbak Union Council \\
\hline
\end{tabular}

Among the sample 6 Union Councils, criteria-based classifications are drawn in Table 4 below. The samples are collected from the sampling frame of 87 Union Councils/Parishads (UPs) of total 11 Sub-districts/Upazilas at Sunamganj district in Bangladesh. The criteria for purposive samples are set by using some parameters given the priori data from Local Governance Programme Sharique, as well as by reviewing some filed documents and preliminary interviews of some UP chairs.

Table 4. Criteria Based Classifications of Samples

\begin{tabular}{ccl}
\hline Criteria No & Criteria & \multicolumn{1}{c}{ Description } \\
\hline Criteria 1 & $\begin{array}{c}\text { Budget Size as well as } \\
\text { Intergovernmental } \\
\text { Transfer }\end{array}$ & $\begin{array}{l}\text { Jamalgonj Sadar and Fenarbak Union Councils are } \\
\text { selected based on the high amount of aggregate } \\
\text { budget size as well as the high amount of } \\
\text { intergovernmental transfer, while Joysree and } \\
\text { Madhanagar Union Councils are selected based on } \\
\text { the low amount of aggregate budget size as well as } \\
\text { the low amount of intergovernmental transfer. }\end{array}$ \\
& $\begin{array}{l}\text { Private/Nongovernmental Support Bhimkhali and } \\
\text { Criteria 2 }\end{array}$ & $\begin{array}{l}\text { Fenarbak Union Councils are selected based on the } \\
\text { high amount of private and other nongovernmental } \\
\text { direct development assistance/support, while }\end{array}$ \\
\hline
\end{tabular}


Criteria 3 Local Revenue Scope as well as Collection

Criteria 4 Political Affiliation
Madhanagar and Joysree Union Councils are selected based on the low amount of private and other nongovernmental direct development assistance/support.

Jamalgonj Sadar and Fenarbak Union Councils are selected based on the high amount of own/local revenue scopes as well as collection, while Joysree and Madhanagar Union Councils are selected based on the low amount of own/local revenue scopes as well as collection.

Joysree and Uttar Sukhair Rajapur Union Councils are selected based on the political affiliation of the UP Chairs with the ruling party, while Bhimkhali and Jamalganj Sadar Union Councils are selected based on the political affiliation of the UP Chairs with a strong opposition party.

There are three key research questions of this study.

i. Why does influence of the influencing phenomena occur in the UP-budgeting decisions? What is the root cause of the problem?

ii. How does such influence occur in the UP-budgeting decisions?

iii. To what extent such influences affect the autonomy of UPs' budgeting decisions?

\subsection{Data Analysis Mapping}

Previous article (Talukdar, 2019) documents the influences in the budgetary process of local government Union Councils in Bangladesh and context specific relative weight of those influences. Now the Figure 3 shows the data analysis mapping, used in this research, focusing on the causes and process of influences and their implications on the budgetary autonomy of UPs in Bangladesh.

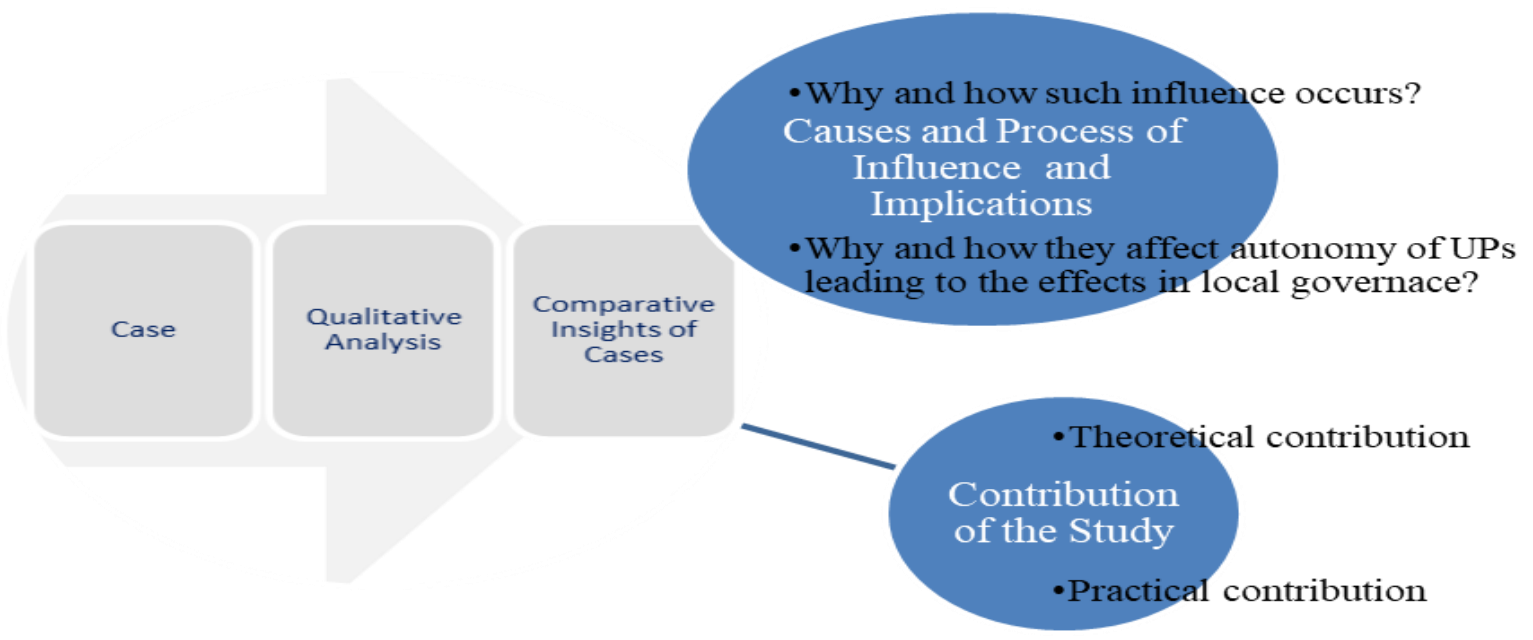

Figure 3. Data analysis mapping 


\section{Research Results}

\subsection{Findings}

Exploring the causal as well as process mechanism of influences, and implications of those on the budgetary autonomy of UPs, leading to the effects in their local governance, is pivotal to this research. Such a pivot in yielding the research results, leading to framing the theoretical and practical contributions of the study, is spinning and moving forward based on the research methodology.

\subsubsection{Why Does Influence Occur?}

Influencing aspects (i.e. source of resources, previous year budget, scarcity of resources, local demands, political and personal traits of the UP Chairs, local problems, legal aspects, UP competence aspects, and council management), as well as dimensions of such influences in the UP-budgetary process, identified in the previous article (Talukdar, 2019), invite further research concerns, for instance, "why do such influences occur?" There are several reasons for influence of the aspects in the UP-budgeting process and decisions, evident from the opinions of UP representatives and field observation notes.

Here is a list of these reasons: a rising scale of community demands, limited scope as well as scale of resources or scarcity of resources (e.g. poor amount of resources available to UPs compared to their needs), excessive dependence on governmental transfers as well as a high magnitude of conditionality, absence of a highly competent and responsible UP leadership, politics on local government, i.e. keeping UPs highly dependent both administratively (e.g. staff shortage and legal dominations) and financially (e.g. leaving UPs with very limited revenue sources), limitations of law or legal constraints, and absence of highly responsible and accountable councils.

According to the Chairman of Fenarbak Union Council, "ensuring check and balance between national government and local government is rationally acceptable. As such placing limited de jure control over Union Councils by law, rules and procedure and establishing a high-level transparency and accountability mechanism is apparently natural, but continual administrative control and excessive conditionality as well as domination with government transfers hamper addressing people-centric and localized priority-based UP-budgeting."

Furthermore, Bhimkhali UP Chair criticizes the politics of national government with local governance. He opines, "I want to run my council in accordance with our community stakeholders, UP committees and councilors, and given my leadership style and vision. But government excessive administrative control and budgetary dominations through tightly coupled conditional transfers undermine both UP-leadership as well as autonomy and spirit of local governance - community driven development, and as such the outcome of UP management, planning and budgeting - local governance - becomes feeble. I, however, strongly encourage government to place here robust oversight and accountability mechanisms." 
On the other hand, Sukhair Rajapur Uttar Union Chairman opines, "government guideline and control help the UPs keep streamlined as the councils are yet to be self-responsible. Ownership and committed leadership as well as responsible UP management, all together still pose an evolving challenge in the context of Bangladesh. Reducing government control and increasing competent as well as responsible UP-councils should go side by side. I rather emphasize at this stage to consider local government, particularly Union Council as a truly strategic partner of the government, and thus recommend involving them in the national strategy and planning, as well as appreciating the UP-approved budget as much as possible, and thus to make government transfers accordingly so as that UPs could overcome the resource constraint to a great extent."

Moreover, Joyshree Union Chairman argues, "rather than the government control and domination, a serious problem here is the scarcity of resources. A Union Council like ours has neither enough of its own revenue and resource base nor sufficient government transfers to address the increasing amount of rational community demands."

Modhanagor UP Chair opines, "due to the government politics with the local government, excessive influences are evident, and effects of such influences undermine autonomy of UPs not only in their budgeting processes and decisions, but also in the overall UP-management and local governance."

Jamalgonj UP Chair points out, "influences in the UP-budgetary process to a great extent are dilemma but inevitable as government transfers are supply driven and less responsive to the actual local demands and highly conditional. On the other hand, local revenue base for the local government UP is poor comparing to the same revenue base for national government, and UPs are not grown yet as self-responsible and committed. Moreover, serious legal constraint is evident that hinders autonomy of local government UPs immensely."

\subsubsection{What Is the Root Cause of the Problem?}

Field notes from observations and experiences of UPs support that the root cause of the problem is the scarcity of UP resources due to leaving Union Parishads with their own very limited revenue sources and insufficient but highly conditional government transfers, as well as the absence of robust ownership of Union Councils with a high sense of obligations to the institution as well as to the community they represent.

The latter part of the ownership - i.e. obligation to the community - is seemingly evident as part of social accountability concerning the vote factor, not in real sense given most cases as is observed during field visits of the current round study on local government autonomy in budgeting decisions. In fact, institutional ownership administers leadership commitment, competency and accountability. Thus, the absence of robust ownership of the elected local government councils, specifically in this case Union Councils, makes ground for highly conditional government transfers.

Government transfer to UPs, however, is justified due to the scarcity of local resources, especially considering UPs' poor local tax base. Devas (1988) observes in this regard that public services to be satisfactorily implemented, it is imperative that there be a mechanism 


\section{Macrothink}

Journal of Public Administration and Governance

ISSN 2161-7104

2019, Vol. 9, No. 2

whereby the resources to match the designated responsibilities are dispensed to the local government. In practice, most local governments are unable to afford taking care of their local needs due to central governments having appropriated for themselves the main revenue sources.

Figure 4 below presents the Union Council's revenue flow diagram, while Table 5 and 6 (revenue and expenditure statements of sample Union Councils) support the theoretical information presented above.

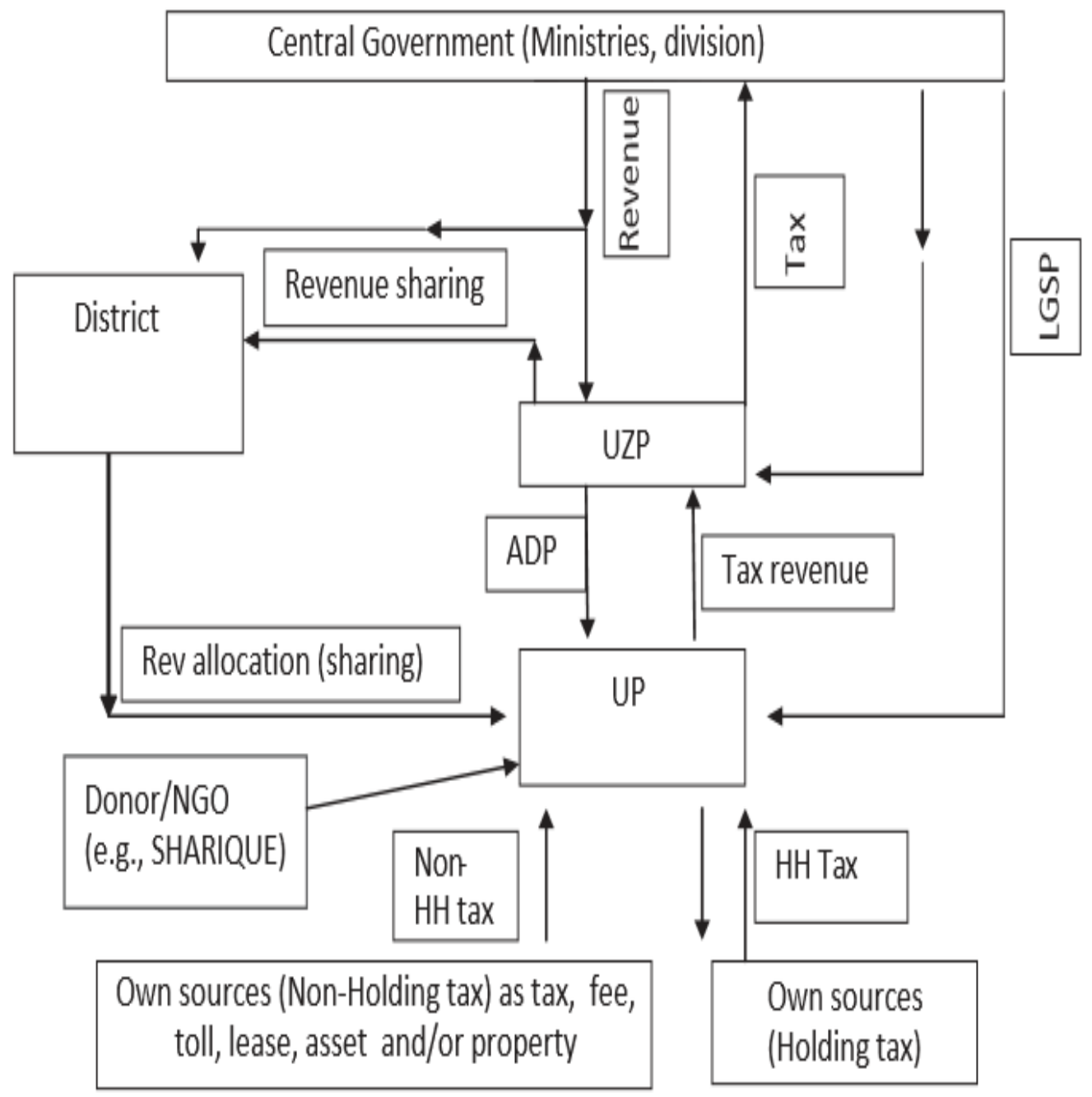

Figure 4. Union council's revenue flow diagram

Source: Rahman et al., 2016:6 
Table 5. Revenue Statement of Union Councils

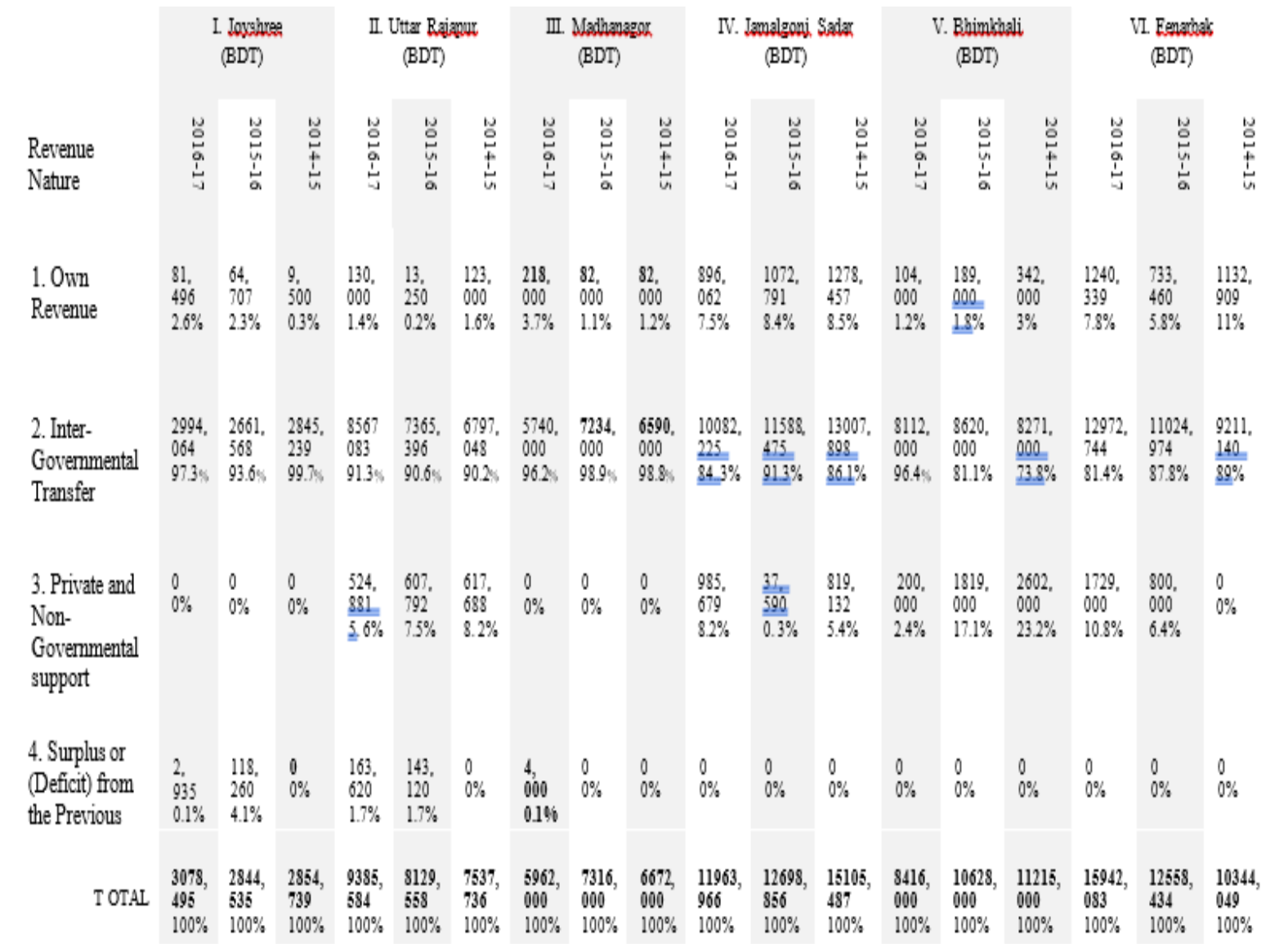

Talukdar (2013) suggests that the budget preparation needs to be participatory and open so that it deliberates impression to the residents that tax and other available resources will be used in their interests. Field observation from this study reveals that UP budget preparation to a certain extent is participatory. The problem, however, is vested with limited local tax base and taxation authority, shortage of human resources, weak capacity of Union Councils to collect their own revenue from household and other taxes, as well as fees, charges etc., and poor competence of these Union Councils to maintain a standard delivery of public services.

Union Councils receive most of their revenue as inter-governmental transfers that include social grants/social safety net support and development assistance, local government project assistance as block grants and portion of pay, and allowance support for council's elected representatives, secretary and village polices. The finding of this study is alike Rahman et al. (2016), although the current round study cautiously observes that local tax base is limited given the distribution of revenue sources between the levels of government - national and local:

UPs lack skilled human resources and adequate incentive to increase their revenue base and manage the taxation system efficiently and effectively. UP tax rates are fixed by the central government as shown in the UP-Model Tax Schedule (Rahman et al., 2016:ix). 
Current round study further observes that Union Councils do not maintain their revenue records and statements properly. Four out of six sample UPs have found difficulties and taken long periods of time to provide appropriate data relevant to the revenue assignments. Such lengthiness in responding to data requirements invites concerns of proper documentations and record keeping that is inherently linked to the weak institutional ownership and accountability.

Building governance safeguards, including citizenry awareness and public disclosure of all revenues as a booklet to prevent revenue leakage and improve revenue transparency, along with the reforms of procedural improvements, increased human resources support and capacity building interventions are crucial requirements to overcome the challenge relating to the lack of institutional accountability. But unless the institutional ownership of UP elected representatives, especially its chairman, grows, accountability framework does not work robustly in this context.

Table 6. Expenditure Statement of Union Councils

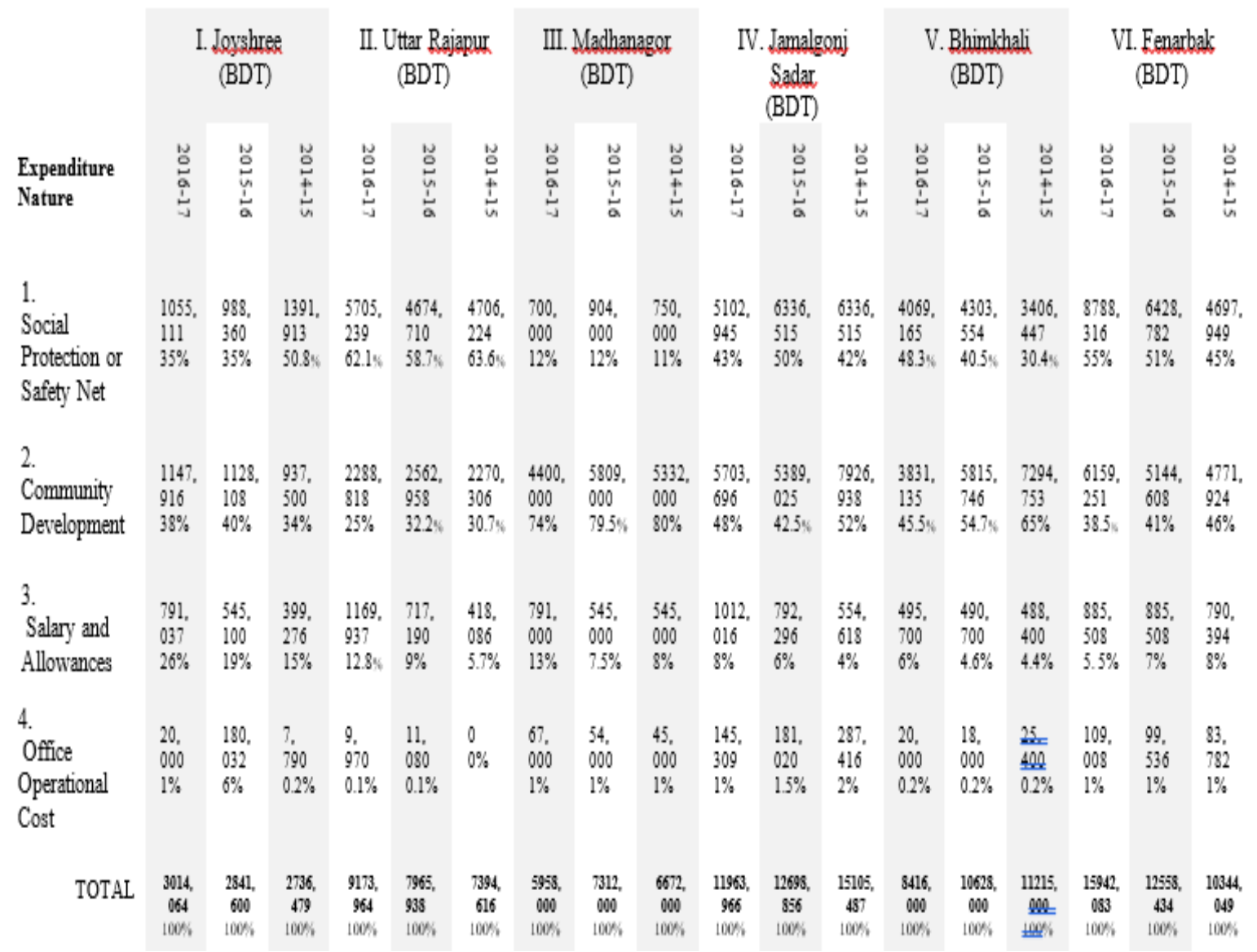

Value of public money is important, and so the expenditure management of Union Councils is crucial to fiscal decentralization. The expected results of decentralization are citizen centric efficient service delivery, and participatory, transparent and accountable local governance. Central to all these aspects are capability and institutional ownership, as well as accountability of local government elected representatives. 
As part of transparency of Union Councils, their expenditure information is a subject that should be made publicly available. Field observations support that current year expenditure information to a certain extent is publicly available, but old expenditure data and information, even the data of recent past fiscal years are not properly recorded and maintained. It took a long period to collect expenditure details of three recent past fiscal years (i.e. 2016-17, 2015-16 and 2014-15). The situation worsened at two out of the six sample Union Councils, where UP secretaries recently transferred, because unsystematic maintenance of records of expenditure statements and documents twisted this problem.

It is important to note that UP expenditure falls under four major categories i.e. social protection or safety net, community development, salary allowances and office operational cost. Data support that compared to the development and social protection expenditure, both salary and allowances, and office operations costs are minimal.

\subsubsection{How Does Such Influence Occur in the UP-Budgeting Decisions?}

Based on the FGDs, discussions with UP representatives, literature review and observation notes, Box 1 is tailored to show how causal relations govern the causal mechanism as well as influence in UP budgeting decisions and beyond.

Box 1: Theoretical skeleton of how causes govern the influence mechanism in Union Council budgeting and beyond

First, scarcity and sources of resources have their influence in making UPs resource-centric focused that is alike Pfeffer and Salancik's (1978) resource dependence theory. These, in effect, make UPs heavily dependent on excessive conditional inter-governmental, and slightly on non-governmental transfers for undertaking their assigned responsibilities and delivering best possible public services, and thus to a certain extent counterfeit the essence of community stakeholders' consultations and undermine the spirit of local governance - responding to community-centric concerns, i.e. community-driven development.

Second, Government transfers are likely to be based on the previous year actual transfers and revised budgets, and the performances as well as outcomes of the previous year transfers in local governance. In effect, last year's actual government transfers tailored the revised budget of the local government Union Councils, and the government's response to the new year budget is not necessarily based on the proposed budget only, but also heavily based on the government's politics of the budgetary process and decisions - i.e. budgetary incrementalism approach of the government that principally counts the performances as well as outcomes of the previous year transfers, also that is alike to the well expressed Wildavsky's seminal work, "The Politics of the Budgetary Process" (Wildavsky, 1964).

Third, evolving local problems as well as increasing demands make UPs concerned regarding external environments to assume and adapt with contingency factors, and make them interconnected with other local government institutes (i.e. Upazila and Zila Parshads) in their areas as well as dependent on national government and non-government for financial support and technical cooperation. Thus, these aspects stress inter-organizational relations (Baker et al. 2011), and allow UPs more interactions with their environments, that is alike Thompson's (1967) and Lawrence and Lorsch's (1967) structural contingency theory. 
Fourth, applications of the relevant government law, rules and regulations, and their dominance go beyond budgeting decisions of UPs to their management as well as local governance, while UP competence aspect matters in their management, planning and budgeting processes and help build their confidence and competitive advantages, effects of which go to the local governance.

Fifth, political and personal traits of the Chair Influence UPs not only in getting competitive advantage in planning and budgeting process and decisions, but also in building a self-responsible Union Council and participatory management as well as robust local governance architecture. Political affiliation and leadership quality also help build political and social networking, and thus ruling party affiliated UP Chairs could have access to some special grants, but they still lose some opportunities if there are strained relations with the concerned Member of Parliament (MP).

Sixth, UP-council management encompasses a UP management culture leading to the magnitude of transparency and accountability in UP-budgeting decisions. Such accountability mechanism helps pave the pathway of robust local governance.

\subsubsection{To What Extent Such Influences Affect the Budgetary Autonomy of UPs?}

It is necessary to employ indicator-based measurement linking with the influencing aspects to the magnitude of budgetary autonomy of Union Councils. Indicators intend to measure the influences and magnitude of autonomy, as well as to connect the dots of influences with their effects on autonomy of UPs in their budgeting decisions, leading to the UPs' autonomy in the wider context of their management and local governance. Indicators further help understand how decisions are taken on UP-budgeting issues. Following the discussions with UP representatives, FGDs, field notes, documents review and previous participant-observations, Table 7 reveals how indicators help measure the influences and autonomy in UP-budgeting decisions, while Box 2 below justifies the indicators, analysis and scale of scores, as well as the scores applied here.

Box 2: Rationale of the indicators and scores set forth

Indicators Here indicators alike questions are set based on the literature review (Davey, 2003; Swift, 2014), analysis of the research problem, conceptual framework and priori knowledge of the context.

Analysis Analysis is drawn following the indicators alike questions, and based on discussions with UP representatives, field notes and previous participant-observations, and extensive literature review (for instance, GOB, 2009; GOB, 2012).

Scores Importantly, the scale of score ( $0-2$, where 2 ranks the highest and 0 represents neutrality) is set by the researcher, but the weight of the score to measure the magnitude of influence and/or autonomy against each indicator alike questions is put forward by the representatives (Chairs) of the six classified sample UPs at Sunamganj District in Bangladesh, following the analysis of the indicators, presented to them during the second-round field visit. Only the average score of the given scores of six sample UP Chairs documented in Table 7. 
Table 7. Measuring influences and autonomy in UP-budgeting decisions

\begin{tabular}{cccc}
\hline Indicators & Analysis & Influence & Autonomy \\
& & $0-2$ & $0-2$ \\
\hline
\end{tabular}

1. Level of stakeholders' consultation and engagement in the planning and budgeting process (i.e. responsiveness to people).

2. Who takes the budgeting decisions (UP Chair/Parishad / Collectively UP Committees and Parishad)?

3. How much real choice do UPs have in determining the budgeting areas concerning local governance and development needs given the stakeholder consultative process and/or its discretions?

4. How much real choice do UPs have in allocating the amount of budget in the prioritized areas?
UP planning committee drafts Annual Plan, based on its Strategic 0 2 Five-Year Plan, and places it to the Ward level for stakeholders' consultations. Also, UP places final draft budget to the open budget meeting to get final round stakeholders' feedback and/or consent.

Findings and demands from the Ward level discussions to be placed to the UP-Standing Committees for screenings, then UP planning committee prepares draft budget to place to the Union Development Coordination Committee (UDCC) for their comments, and then UP reviews and places the final draft to the open budget meeting to the public and approves the budget at the UP meeting (with or without adjustments).

In practice, UPs do not have real choice in determining the budgeting areas concerning local governance and development needs as the influence of source of resources and scarcity of resources is strongly evident here. UP budget largely depends on inter-governmental transfers, while government transfers are conditional with rules, regulations and circulars.

It is evident considering the local problems (i.e. diversity as well as 12 magnitude of the problems, area-based priority and individual stakeholders' influence), and local demands (i.e. diversity, magnitude, 


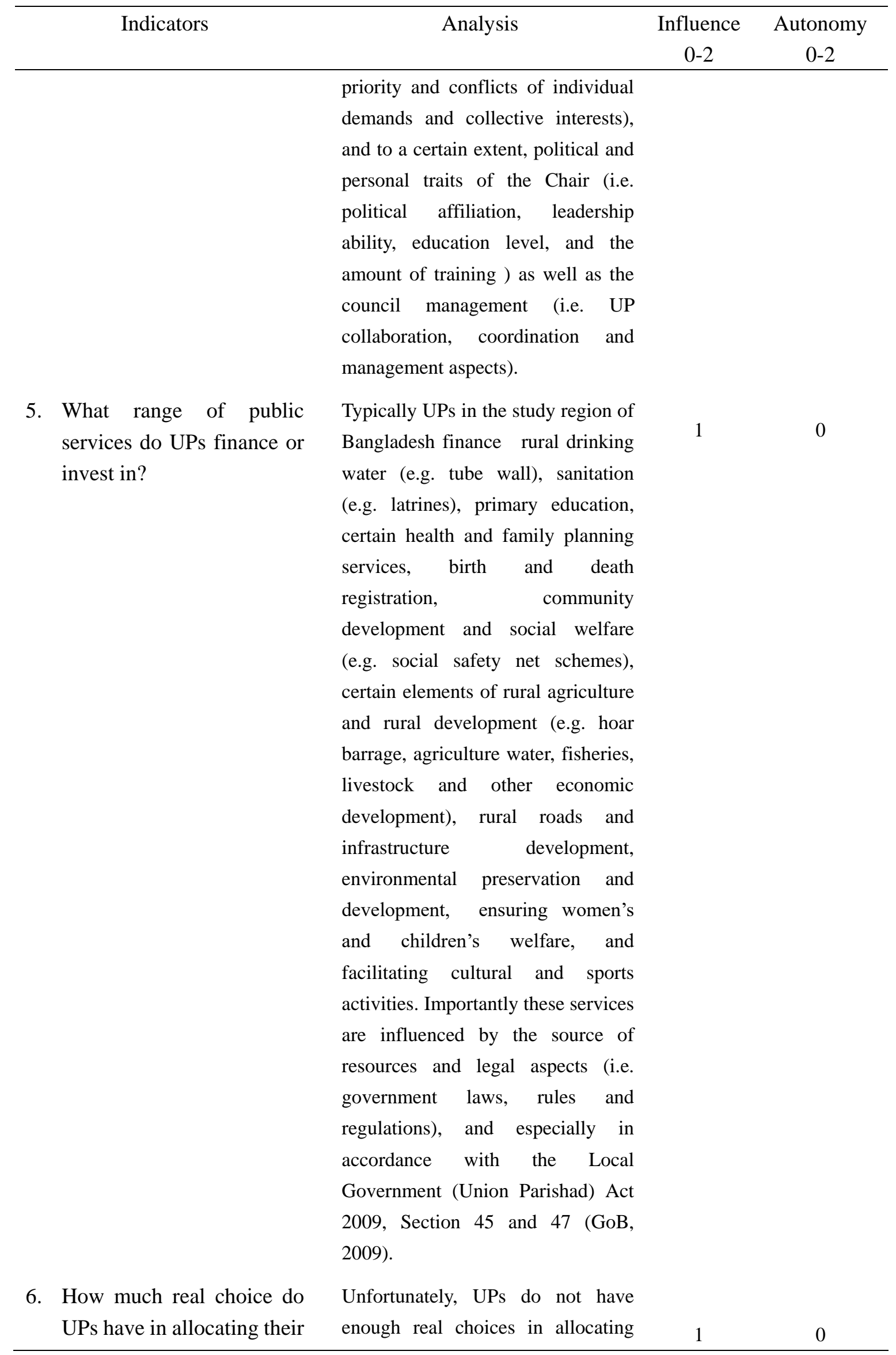




\begin{tabular}{|c|c|c|c|c|}
\hline \multicolumn{2}{|r|}{ Indicators } & $\begin{array}{c}\text { Analysis } \\
\text { their budget to individual services }\end{array}$ & \multirow{2}{*}{$\begin{array}{c}\text { Influence } \\
0-2\end{array}$} & \multirow{2}{*}{$\begin{array}{c}\text { Autonomy } \\
0-2 \\
\end{array}$} \\
\hline & $\begin{array}{l}\text { budget to individual } \\
\text { services? }\end{array}$ & $\begin{array}{l}\text { their budget to individual services } \\
\text { as these are determined by the } \\
\text { conditionality of source of resources } \\
\text { and influenced by the scarcity of } \\
\text { resources. Budget here largely } \\
\text { depends on conditional government } \\
\text { line departments and Local } \\
\text { Government Support Project } \\
\text { (LGSP) transfers. }\end{array}$ & & \\
\hline & $\begin{array}{l}\text { Do the UPs have the } \\
\text { authority to select social } \\
\text { safety net beneficiaries and } \\
\text { allocate funds for them? }\end{array}$ & $\begin{array}{l}\text { Usually UPs do select social safety } \\
\text { net beneficiaries and allocate funds } \\
\text { for them following the conditions } \\
\text { and guidelines concerned with the } \\
\text { government departments that are } \\
\text { transferring such funds to UPs. }\end{array}$ & 1 & 1 \\
\hline 8. & $\begin{array}{l}\text { Do they have the authority } \\
\text { to allocate funds for social } \\
\text { dispute resolutions (i.e. } \\
\text { Shalish and activating } \\
\text { Village Court)? }\end{array}$ & $\begin{array}{l}\text { In the study region of Bangladesh, } \\
\text { there is no project support or } \\
\text { departmental fund transfer for this } \\
\text { purpose. Thus, here UPs may } \\
\text { allocate funds for social dispute } \\
\text { resolutions only from local or their } \\
\text { own revenue sources with the } \\
\text { government's consent. The Local } \\
\text { Government (Union Parishad) Act } \\
2009 \text { (Section 54), prescribes the } \\
\text { expenditure area from the Union } \\
\text { Council's own fund, and sets } \\
\text { parameters by the provision of } \\
\text { government control, especially by } \\
\text { the Section 54(3) that restricts the } \\
\text { UP spending from its own surplus } \\
\text { funds by the requirement of } \\
\text { government direction for the UP } \\
\text { (GoB, 2009). In practice, they } \\
\text { hardly have their own resource } \\
\text { surplus, beyond maintaining cost } \\
\text { and sharing their salary along with } \\
\text { the government support. }\end{array}$ & 2 & 0 \\
\hline 9. & $\begin{array}{l}\text { Do they have the authority } \\
\text { to allocate funds for local }\end{array}$ & $\begin{array}{l}\text { They do not have independent } \\
\text { authority to allocate funds for local }\end{array}$ & 2 & 0 \\
\hline
\end{tabular}




\begin{tabular}{|c|c|c|c|}
\hline Indicators & Analysis & $\begin{array}{l}\text { Influence } \\
0-2\end{array}$ & $\begin{array}{l}\text { Autonomy } \\
0-2\end{array}$ \\
\hline $\begin{array}{l}\text { infrastructure development } \\
\text { initiatives? }\end{array}$ & $\begin{array}{l}\text { infrastructure development } \\
\text { initiatives as they do not have } \\
\text { enough revenue/resources of their } \\
\text { own. Such activity is heavily } \\
\text { dependent on source of resource } \\
\text { (i.e. transferring departments } \\
\text { allocate funds with strict conditions } \\
\text { and guidelines) and government's } \\
\text { approval. As mentioned above, } \\
\text { government control and domination, } \\
\text { by the Local Government (Union } \\
\text { Parishad) Act 2009, Section 54, are } \\
\text { evident here (GoB, 2009). }\end{array}$ & & \\
\hline $\begin{array}{l}\text { 10. Do the UPs have the } \\
\text { authority to allocate funds } \\
\text { for entrepreneurial } \\
\text { initiatives? }\end{array}$ & $\begin{array}{l}\text { UPs have bounded authority to } \\
\text { allocate funds for limited } \\
\text { entrepreneurial initiatives if they } \\
\text { have their own resource/revenue } \\
\text { capacity for those initiatives. The } \\
\text { Local Government (Union } \\
\text { Parishad) Act } 2009 \text {, Section } 55 \text { (2) } \\
\text { allows UPs to invest their own } \\
\text { funds (GOB, } 2009 \text { ). In contrast, } \\
\text { government control and domination, } \\
\text { by the Local Government (Union } \\
\text { Parishad) Act } 2009 \text { Section } 54 \text {, are } \\
\text { evident here (GoB, 2009). In } \\
\text { practice, they do not have enough } \\
\text { revenue or resources (i.e. resource } \\
\text { constraint) of their own. Also, no } \\
\text { external resource support is } \\
\text { available for that. }\end{array}$ & 2 & 1 \\
\hline $\begin{array}{l}\text { 11. Do they have the authority } \\
\text { to allocate funds for local } \\
\text { government innovations } \\
\text { and development? }\end{array}$ & $\begin{array}{l}\text { UPs may allocate funds for limited } \\
\text { local government innovations and } \\
\text { development with their own } \\
\text { revenue/resources with the } \\
\text { government's approval. As } \\
\text { mentioned above, government } \\
\text { control and domination, by the } \\
\text { Local Government (Union } \\
\text { Parishad) Act 2009, Section 54, are }\end{array}$ & 2 & 1 \\
\hline
\end{tabular}




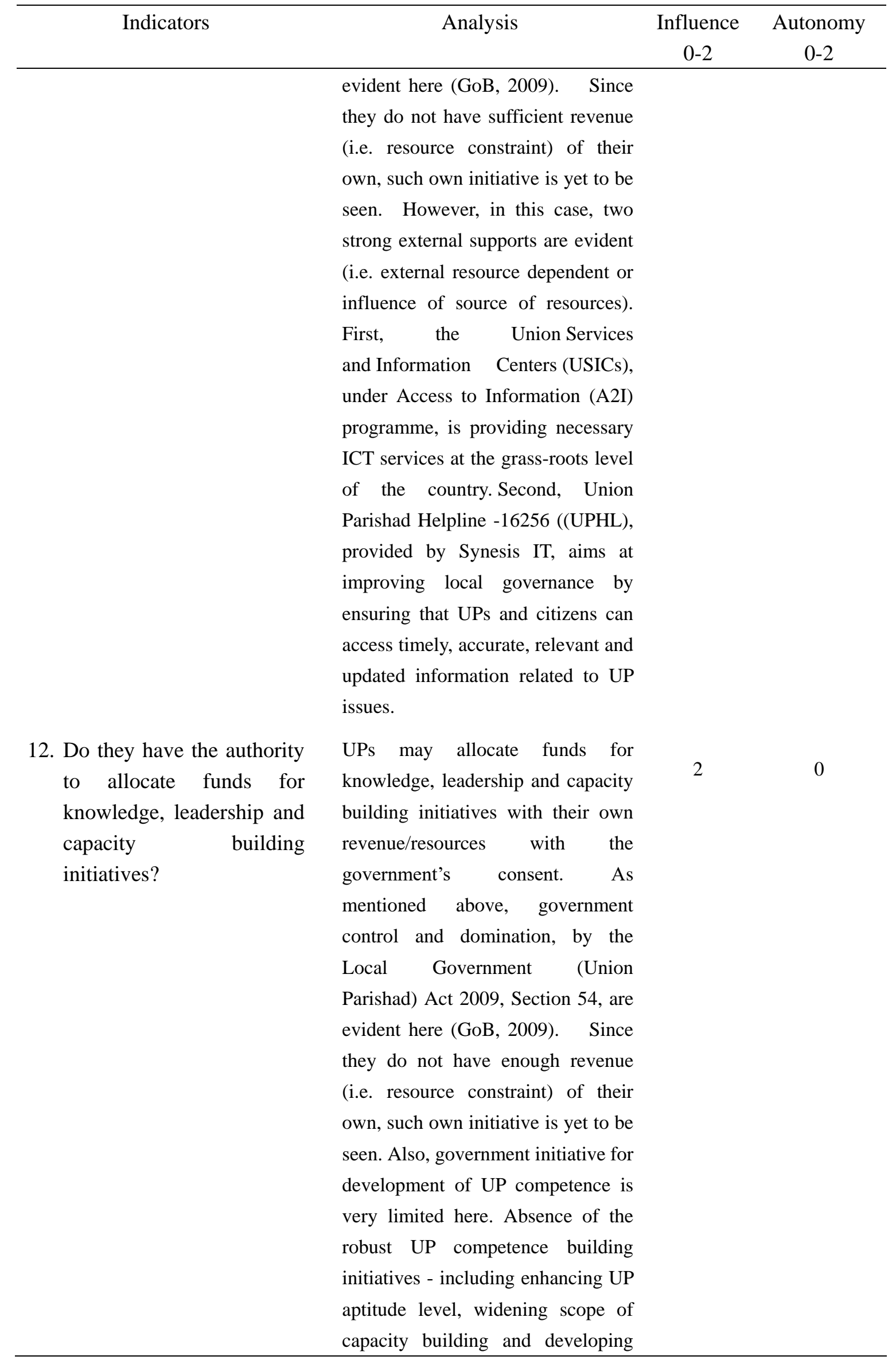


13. Do they have the authority to allocate funds for local recruitment as well as staff payment?
14. Do the UPs have the authority to provide input in the national budgeting process? Do they have the authority to provide input in the national five-year planning?

15. Do the UPs have the authority to determine the amount required from the government (inter-governmental transfer)? training opportunity for the councils - undermines the competence, competitive advantage and autonomy of UPs.

Normally they do not have authority of recruitment. Such activity is done 2 1 by the pertinent government authority and determined by the law and rules. However, UPs with their own resources are supposed to cost share with the government for council as well as staff payment until they are capable enough to maintain this independently (i.e. influence of resource constraint and source of resources)

Normally UPs do not have scope to provide input either in national budgeting process, or in national five-year planning. No legal support (i.e. absence of legal aspect).

Yes, they do have such authority in a sense that the UPs submit their 1 1 approved budgets to the Upazila Executive/Nirbahi Officer (UNO) with cc to Deputy Director of Local Government (DDLG) and Deputy Commissioner (DC), in which they show the required amounts from the government (inter-governmental transfers). But the government rarely responds to their actual needs, rather it applies incremental approach to the broad heads of the budgets, usually based on the previous year budgetary allocations to them and their expenditure performances and outcomes (i.e. 


\begin{tabular}{|c|c|c|c|}
\hline Indicators & Analysis & $\begin{array}{c}\text { Influence } \\
0-2\end{array}$ & $\begin{array}{c}\text { Autonomy } \\
0-2\end{array}$ \\
\hline
\end{tabular}

16. Do they have the right and scope to explore civil society donations/funds?
Yes, they do have right and scope to explore civil society donations/funds within the country. In case of foreign and/or multilateral agency grants or cooperation either these need to come directly through government or by the intermediary legal entity/civil society organization as well as indirectly through the government. Here political and personal traits of the UP Chair and council's competence matter much.

17. Do they have the right and scope to explore public-private partnerships?

The Local Government (Union Parishad) Act 2009, Section 55 (2) allows UPs to invest their own funds, and section 55 (3) of this
18. Do they have the right to explore sub-national borrowing scopes?

19. Do they have the right to expand local resource net/mapping? same Act allows the creation of a special account with the consent of the government $(\mathrm{GoB}, 2009)$. These imply that UPs have the right and scope to explore public-private partnerships as well. But in practice, they do not have enough of their own funds/revenue to do so. In summary, here on one hand, there is legal support/influence, and on the other, resource constraint is a strong hindrance. Also, political and personal traits of the UP Chair and council's competence matter much here.

No, they do not. There is no legal support for that.

1

0

Yes, they do have the right to expand local resource net/mapping 2 1 following the Union Parishad model tax schedule 2012 (GOB, 2012), i.e. 


\begin{tabular}{|c|c|c|c|}
\hline Indicators & Analysis & $\begin{array}{c}\text { Influence } \\
0-2\end{array}$ & $\begin{array}{c}\text { Autonomy } \\
0-2\end{array}$ \\
\hline \multirow[t]{2}{*}{$\begin{array}{l}\text { 20. Do they have the right to } \\
\text { determine the rates of the } \\
\text { local taxes and charges? }\end{array}$} & $\begin{array}{l}\text { influence of legal aspects. Given the } \\
\text { model tax Schedule, UPs in the } \\
\text { study area do not have access to the } \\
\text { many local resources (e.g. natural } \\
\text { resources and water bodies like } \\
\text { haor-bill). Besides, political and } \\
\text { personal traits of the UP Chair and } \\
\text { council's competence matter much } \\
\text { here. } \\
\text { No, they do not have right to } \\
\text { determine the rates of the local } \\
\text { taxes and charges. These are } \\
\text { determined by the government at } \\
\text { the Union Parishad model tax } \\
\text { schedule } 2012 \text { (GOB, 2012), i.e. } \\
\text { influence of legal aspects. }\end{array}$ & 2 & 0 \\
\hline & Total & $29 / 40$ & $16 / 40$ \\
\hline
\end{tabular}

Influences > Autonomy of UPs in their budgeting decisions $=29>16$

It seems that the magnitude of influences is almost double than that of the autonomy of UPs in their budgeting decisions. Thus, autonomy of UPs at Sunamganj District in Bangladesh in their budgeting decisions is a serious apprehension in the study of decentralization and local governance.

6.1.5 How do the Influences Affect Autonomy of UPs' Overall Management, Leading to the Effects in Their Local Governance?

Bhimkhali UP Chair's opinion, as cited to understand the causes of the influence, is partly relevant to comprehend how the influences affect the autonomy of UPs' overall management, leading to the effects in their local governance. Relevant part of the opinion is documented here again: Government excessive administrative control and budgetary dominations through tightly coupled conditional transfers undermines both UP-leadership as well as autonomy and spirit of local governance - community driven development, and as such outcome of the UP management, planning and budgeting - i.e. local governance - becomes feeble.

Modhanagor UP Chair opines that excessive influences undermine autonomy of UPs not only in their budgeting processes and decisions, but also in the overall management as well as in the outcome of both budgeting decisions and UP governance (i.e. to the community governance and development - local governance).

Jamalgonj Sadar UP Secretary, following his Chair's dialogue, draws attention to the fact that influences are inevitable and budgetary autonomy of UPs continues to be lessen unless the government transfers transform to be responsive to the local demands and become less 
conditional, as well as UPs become highly competent, committed and self-responsible, and UPs get wide range of local revenue sources under their jurisdiction lessening the national government revenue sources in the local area.

Furthermore, UP Chair of the Jamalgonj Sadar suggests making legal reforms to establish minimally acceptable autonomy in UP-budgeting as well as its service delivery, and in UP governance and development process. The UP Chair refers here to the two legal points. The first point he is making is that the Local Government (Union Parishad) Act 2009 (Section 54) deters UP autonomy, even at a context where UP could have maximized its own revenue. The second point he is making is that increasing local tax-base/net by trading off national government resource base at the local level is essential here, as the maximum possible amount can be collected from the local revenue assignments is relatively very insufficient compared to the aggregate budget of a year.

The research can test the validity of this statement given the data of the sample six UPs. Table 8 below shows this validity test.

Table 8. Maximum possible amount of UP own revenue compared to the budget

\begin{tabular}{lccc}
\hline Sample UPs & $\begin{array}{c}\text { Aggregate } \\
\text { Budget } \\
2016-17\end{array}$ & $\begin{array}{c}\text { Maximum possible } \\
\text { amount/ } \\
\text { scope of own revenue }\end{array}$ & Ratio \\
\hline Fenarbak & 18200,000 & 1343,000 & $14: 1$ \\
Jamalgonj Sadar & 20428,000 & 1611,000 & $13: 1$ \\
Joysree & 7972,000 & 300,000 & $27: 1$ \\
Modhanagar & 8050,000 & 300,000 & $27: 1$ \\
Uttar Sukhair Rajapur & 8628,000 & 650,000 & $13: 1$ \\
Bhimkhali & 13487,000 & 595,000 & $23: 1$ \\
Average & 12794167 & 799,833 & $16: 1$ \\
\hline
\end{tabular}

Empirical results of this test prove the statement of Jamalganj Sdar UP Chair: The maximum possible amount can be collected from the local revenue assignments is relatively very insufficient comparing to the aggregate budget of a year.

Thus, linking with the former part of statement of Jamalganj Sdar UP Chair, there are two options here: first, increasing local tax-base/net by trading off national government resource base at the local level, and second, tax from the all local sources should be collected by local governments, and in turn these governments shall contribute equitably to the national government as well.

\subsection{Contributions}

The contribution of the study is revealing the causal mechanism as well as how such process works that leads to shape the dominant implications in UP autonomy and local governance. Such contribution is tailored-made based on the grounded theory data-analytic principles - 
'incident-to-incident' and 'constant-comparison' - which ensures that the themes emerging remain grounded in the data-set, and thus firmly ensuring 'fit and relevance' (Glaser, 1978).

\subsubsection{Theoretical Contribution}

This includes causal mechanism as well as process and dominant implications in UP autonomy and local governance, and rationality of the government conditions and control on local government like Union Council in relation to the UPs' self-responsibility and competence, as well as balance between central-local authority.

Rising the scale of community demands, limited scope of revenues, excessive dependence on the governmental transfers as well as high magnitude of conditionality of such transfers, absence of highly competent and responsible UP leadership as well as councils, government politics with local government i.e. keeping UPs highly dependent both administratively (e.g. staff shortage and legally dominations) and financially (e.g. leaving UPs with very limited revenue sources), limitations of law or legal constraints help make excessive as well as diversified influences of the influencing phenomena in UP-budgeting process and decisions. This theoretical analysis of causal relations goes along with the theoretical frame of Davey (2003) regarding fiscal decentralization:

Fiscal decentralization covers two interrelated issues: First, division of spending responsibilities as well as revenue sources between levels of government. Second, the amount of discretion given to regional and local governments to determine their expenditure and revenues (Davey, 2003:1).

Box-1, at the preceding chapter, portrayed the theoretical analysis of how causal relations govern the causal mechanism as well as influence in UP budgeting decisions and beyond. Influence of concerned phenomena in UP-budgeting process and decisions does not certainly collide with budgetary autonomy of UPs, but the effects of such influences are evident with varying degrees and dimensions on the budgetary autonomy of UPs, and even to their overall management and local governance.

Following the indicator-based empirical analysis, it seems that magnitude of influences is almost double than that of the autonomy of UPs in their budgeting decisions. Thus, the autonomy of UPs at Sunamganj District in Bangladesh in their budgeting decisions is a serious apprehension in the study of decentralization and local governance. Same would be true all over the country, even globally if context as well as influencing phenomena and magnitude of the influences are more likely similar in other areas of the country or globe.

To understand the rationality of the government conditions and control on Union Councils, it is important to revisit the empirical opinions of two respondents - Secretary of Jamalgonj Sadar UP and Chairman of Sukhair Rajapur Uttar Union. Former's opinion is documented at sub-chapter 'Implications of the influences', and the latter one's is described at sub-chapter 'Causes and the root cause' under the "Findings". Such opinions and empirical observations put forwarded a theoretical lens that has two aspects: First, reducing government control and increasing competent as well as responsible UP-councils should go side by side, that is aligned with Davey (2003): 
Extent local discretion would be matter of balance between national and local interests.

Neither central control nor local autonomy should have unchallenged priority (Davey, 2003:7).

Second, emphasizing the call for local government, particularly the Union Council to make a truly strategic partner of the government, and thus to involve them in the national strategy build-up and planning as well as budgeting process. This goes with United Cities of Local Government (2011):

In many countries local governments are not adequately equipped to perform their functions well and to become more effective partners of higher-level governments in meeting pressing common goals (UCLG, 2011:13).

Management of public services could be improved in terms of accountability and performance, if they are entrusted to the local level officials, compared to the far detached national bureaucrats (Ostrom et al. 1993). But empirical observations support that there are lots of other deliberations here. Rationality of the government conditions and control on local government Union Councils in Bangladesh is tied to the crisis of self-responsibility as well as competence of Union Council Chairs and members.

Government conditions are further entrenched in the inevitable inter-governmental resource dependency and call for ensuring financial accountability and monitoring the performance of local government Union Councils. However, the community perception of 'accountability' is quite different from the accountability frame academics advocate. Figure 5 below illustrates the comprehensive accountability framework of the local government Union Councils in Bangladesh.

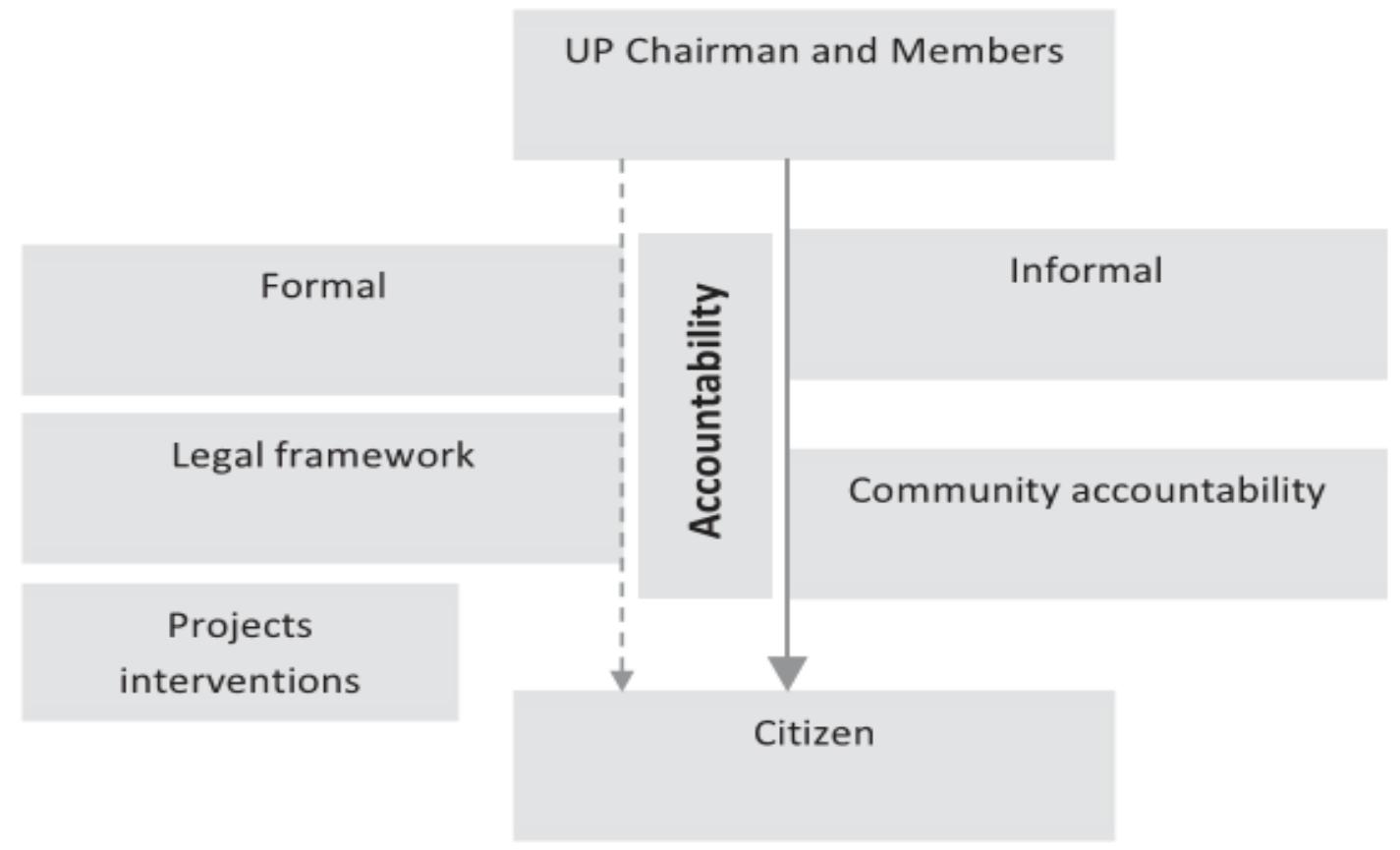

Figure 5. Formal and informal accountability flow of UPs

Source: Ahmed et al., 2016: 6 
Both the UP representatives and the general citizens put less emphasis on formal accountability tools and concerns, but more on the social accountability with traditional and informal practices (Ahmed et al., 2016:42). Observation of the current research also supports Ahmed et al. (2016). Thus, the UPs' social contributions and performance would be highly appreciated if those could be documented properly. Contrary to this, field observations reveal that institutional ownership as well as competence of UPs to manage their revenue and expenditure portfolio sensibly is a serious concern that also justifies the conditionality and guidelines of government transfers to them.

In fact, ownership, competence as well as financial accountability and conditionality are intrinsically linked. These are also linked to an important unresolved question that is beyond this research's terms of reference: What make the local government UP representatives seriously interested to be elected there? or What are the incentives and motivational factors for them to be elected there? Their salary and formal benefits (as shown in the expenditure statement at Table 6) are very poor. The 2016 study of Ahmed et al. partly raise same the same concern. Ahmed et al. (2016), however, presents a precise response to the unresolved question:

By influence of the positions they (elected members and chairs) can grab many lucrative businesses and make money. The people do not think that UP representatives are making money from UPs rather they utilize UP leadership identity in exploiting many other lucrative money-making ventures (Ahmed et al., 2016:45).

Nonetheless, Ahmed et al.'s (2016) response is not evidence based, and still could be treated as anecdote. Further study to understand the political psychology of UP representatives regarding their interest for being elected, is a must.

\subsubsection{Practical Contribution}

Practical contribution of the study proves the fact of maximum level local revenue collection cannot solve the autonomy crisis of UPs considering the current revenue base and legal constraints.

Empirical results of the test (as shown in Table 8) in the context of UPs at Sunamganj District in Bangladesh, proves the following part of the statement of Jamalganj Sadar UP Chair: The maximum possible amount can be collected from the local revenue assignments is relatively very insufficient comparing to the aggregate budget of a year. The research solves this problem providing the two options: first, increasing local tax-base/net by trading off national government resource base at the local level, and second, tax from the all local sources should be collected by local governments and then this collected tax shall contribute equitably to the national government as well.

Yet the solution above alone cannot solve the autonomy crisis of UPs considering the legal constraints that are applicable for the countrywide:

The Local Government (Union Parishad) Act 2009 (Section 54) deters the UP autonomy even it could maximize its own revenue. It determines the expenditure area of UP from the 
own fund of the same, and sets parameter by the provision of government control, especially by the Section 54(3) that controls the UP spending even from its surplus own funds by placing the provision of government direction requirement for the same (GOB, 2009:35-36).

\section{Recommendations and Conclusion}

\subsection{Recommendations}

\subsubsection{Suggestions Based on the Findings and Inferences}

First, focus should be drawn on how to build up ownership, self-responsibility, committed leadership and competence of UP-councils. Once these grow the basis for lessening government conditions to the inter-governmental transfers and/or increasing local tax base by trading of national government resource base at the local level will pave the way.

Second, following the research findings, it is recommended that the section 54(3) of The Local Government (Union Parishad) Act 2009 be amended to strengthen the local government innovations and to motivate local government Union Councils for focusing on their own revenue collection. Section 54 of the abovementioned Act/Law determines the expenditure area, the revenue based of which from the own source of the Union Councils. It further sets the parameters by the provision of government control, especially by the Section 54(3) that controls the UP spending even from its own surplus funds by placing the provision of government direction requirement for the UP (GoB, 2009:35-36).

Third, following the opinions of the UP representatives and based on empirical observations, the research suggests that UPs focus on building up strategic partnerships with other levels of local governments, not just with the national government, use the common source of resources effectively, as well as strengthen inter-connectedness for doing advocacy together on common issues of local governance.

7.1.2 Clear Statement of Action That Should be Taken Based on the Suggestions, and by Whom

Increasingly building up competent and responsible UP-councils as well as leadership requires robust capacity building initiatives by the government on one hand, and changing attitudes of Union Council members, chair and secretary, as well as the government on the other. The former can be done by the local government division by initiating the strengthening of local governance projects, while the latter is challenging and requires advocacy campaigns to run by building a local governance platform by the local government institutes themselves. Thus, the latter is closely linked to the third recommendation.

Increasing the local tax-base/net of UPs also requires legal reforms to be done by the government, particularly reforms of the Union Parishad model tax schedule 2012, and subsequent changes of the government tax net.

Regarding the legal reform in addressing the autonomy crisis of UPs, mentioned under the second recommendation, the government requires to amend section 54 of the Local Government (Union Parishad) Act 2009 and delete 54(3) from the same act. 
Building strategic partnership of UPs with other levels of local governments, not just with the national government, initially requires inviting dialogue among the local government institutes by the Local Government Division under Ministry of LGRD\&C of the Government of Bangladesh.

\subsection{Concluding Remarks}

\subsubsection{Conclusion With a Clear Link to the Introduction}

Influence of the concerned phenomena in UP-budgeting process and decisions does not certainly or always collide with autonomy of UPs in their budgeting decisions, but the effects of such influences are evident on the budgetary autonomy of UPs with varying degrees and dimensions. Indicator-based empirical analysis reveals that the magnitude of influences is almost double than that of the autonomy of UPs in their budgeting decisions. Thus, the autonomy of UPs at Sunamganj District in Bangladesh in their budgeting decisions is a serious concern in the study of decentralization and local governance. The same would be true all over the country or even globally if the context as well as the influencing phenomena and magnitude of the influence are more likely similar in other areas of the country or globe.

At the beginning (the opening of introduction), the research outlies a proposition, which shows that demands for public goods and services are increasingly exceeding the supply at local governments in Bangladesh and elsewhere, particularly in developing countries. Yet the revenue assignments of local governments in most developing countries including Bangladesh are often very poorly designed and very limited.

The research findings clearly support and strengthen its opening statement. The research proves that the maximum possible amount that can be collected from the local revenue assignments is relatively very insufficient compared to the aggregate budget of a year (as shown in Table 8). Thus, the maximum level local revenue collection cannot solve the autonomy crisis of UPs considering the current revenue base and legal constraints.

Consequently, increasing local tax-base/net by trading off national government resource base at the local level along with the legal reforms is one way to establish minimum autonomy through growing its own resource capacity. But this alone cannot provide the resources needed to an UP considering its growing local problems and increasing community demands.

Thus, it further requires flexible as well as less conditional inter-governmental transfers following its approved budget submitted to the government. Government's incrementalism approach in transferring funds based on the previous year transferred amount and performance audit should not be stereotyped, rather must be responsive to the UP approved budget submitted to the appropriate authority of the government. Otherwise, the citizenry involvement (as shown in Table 7), as well as stakeholder consultative processes, for example, ward shaba meetings and UP open-budget meetings, all might superficially become counterfeit.

Rationality of the government conditions and control on local government Union Councils is tied to the crisis of self-responsibility and competence of Union Council Chairs and members. 


\section{Mll Macrothink}

Journal of Public Administration and Governance

ISSN 2161-7104

2019, Vol. 9, No. 2

Government conditions are further entrenched in the inevitable inter-governmental resource dependency and call for ensuring financial accountability and monitoring the performance of local government Union Councils.

The research further appreciates the fact that central hindrance towards effective functioning of the local government Union Councils is the crisis of ownership and competence of UP representatives. Local governments in Bangladesh, particularly Union Councils, have yet to grow a high sense of self-responsibility, commitment as well as competent leadership and capable councils. Once these grow the basis for lessening government conditions to the inter-governmental transfers and/or increasing local tax base by trading off national government resource base at the local level will pave the way.

The research, also, takes a stance - reducing government control and increasing competent as well as responsible UP-councils and leadership should go side by side. It also suggests placing here robust oversight and accountability mechanisms.

\subsubsection{Wider Consideration Outside the Terms of Reference of the Study}

Influences of the influencing aspects or phenomena go beyond the UP-budgeting decisions to its overall management as well as local governance, the discussion of which falls outside the terms of reference of this research (as conferred in the discussion of findings).

7.2.3 Requirement of Further Research Relevant to New Questions as Well as Scopes Emerged from This Study

There are two issues here that require further study:

First, further study requires an in-depth understanding of how the influencing phenomena affect beyond the UP-budgeting decisions to its overall management as well as local governance. In other words, to what extent do these influencing phenomena affect the autonomy of UPs in their overall management and local governance?

Second, further study is necessary to understand the reasons why UP representatives are interested in being elected and what kind of incentives are attractive for them to be elected despite their salary and formal benefits being very poor, as shown in the expenditure statement at Table 6.

\section{References}

Acevedo, M., \& Krueger, J. (2004). Two egocentric sources of the decision to vote: The voter's illusion and the belief in personal relevance. Political Psychology, 25(1), 115-134. https://doi.org/10.1111/j.1467-9221.2004.00359.x

Ahmed, T. (2014). Findings Overview for LGSP-II in Jessore, Nilphamari and Satkhira. Manusher Jonno Foundation, CARTA Program. Dhaka.

Ahmed, T., Ahmmed, K. N., \& Razzaque, F. (2016). Social Accountability Mechanisms : A Study on the Union Parishads in Bangladesh (Special Publication Series No. 02, March 2016). 
Aminuzzaman, S. (2010). Local Government and Development in Bangladesh: Lessons Learned and Challenges for Improving Service Delivery of Union Parishad (UP), the paper was drafted under Local Governance Support Project-Learning and Innovation Component (LGSP-LIC) for LGD, Ministry of LGRD\&C, Government of People's Republic of Bangladesh.

Axelrod, D. (1995). Budgeting for Modern Government. (2nd Editio). New York: St. Marin's Press, Inc.

Baker, E., Kan, M., \& Teo, S. T. T. (2011). Developing a collaborative network organization: leadership challenges at multiple levels. Journal of Organizational Change Management, 24(6), 853-875. https://doi.org/10.1108/09534811111175797

Bruin, W. B., Parker, A. M., \& Fischhoff, B. (2007). Individual differences in adult decision-making competence. Journal of Personality and Social Psychology, 92(5), 938-956. https://doi.org/10.1037/0022-3514.92.5.938

Coston, J. (1998). Administrative Avenues to Democratic Governance: The Balance of Supply and Demand. Public Administration and Development, 18(5), 479-493. https://doi.org/10.1002/(SICI)1099-162X(199812)18:5<479::AID-PAD37>3.0.CO;2-Y

Cottam, M. L., Dietz-Uhler, B., Mastors, E., \& Preston, T. (2010). Introduction to Political Psychology (2nd ed.). New York, NY: Psychology Press. https://doi.org/10.4324/9780203848777

Dauda, C. L. (2006). Democracy and Decentralization: Local Politics, Marginalization and Political Accountability in Uganda and South Africa. Public Administration and Development, 26, 291-302. https://doi.org/10.1002/pad.411

Davey, K. (2003). Fiscal Decentralization. Key Note Paper.

Devas, N. (1988). System of Allocation of Government Funds to Local and Regional Governments. In E. B. Prantilla (Ed.), Financing Local and Regional Development in Developing Countries: Selected Country Experiences. Nagoya: UNCRD.

Dietrich, C. (2010). Decision Making: Factors that Influence Decision Making, Heuristics Used, and Decision Outcomes. Inquiries Journal, 2(2).

DiMaggio, P. J., \& Powell, W. W. (1983). The iron cage revisited: Institutional isomorphism and collective rationality in organizational fields. American Sociological Review, 48, 147-160. https://doi.org/10.2307/2095101

Eisenhardt, K. M. (1989). Agency theory: An assessment and reviw. Academy of Management Review, 14(1), 57-74. https://doi.org/10.5465/amr.1989.4279003

Gianakis, G. A., \& McCue, C. P. (1999). Local Government Budgeting. A Managerial Approach. West Port, CT: Praeger.

Glaser, B. (1978). Theoretical Sensitivity. Mill Valley, CA: Sociology Press. 
Glaser, B. (1992). Basics of Grounded Theory Analysis. Mill Valley, CA: Sociology Press.

GOB (2012). Union Parishad model tax schedule 2012. Local Government Division: Dhaka.

GOB. (2009). The Local Government (Union Parishad) Act 2009. Local Government Division: Dhaka.

Gouldner, A. W. (1954). Patterns of Industrial Bureaucracy. Glencoe, IL: Free Press.

Hannan, M. T., \& Freeman, J. H. (1977). The population ecology of organizations. https://doi.org/10.1086/226424

Henley, D. (Ed.). (1992). Public Sector Accounting and Financial Control (4th ed.). London and New York: Chapman \& Hall.

Hicks, J. F., \& Kaminski, B. (1995). Local Government Reform and Transition from Communism: The case of Poland. Journal of Developing Societies, 9(1), 1-20.

Hodgson, G. (2006). What are Institutions? Journal of Economic Issues, 40(1), 1-25. https://doi.org/10.1080/00213624.2006.11506879

Jullisson, E. A., Karlsson, N., \& Garling, T. (2005). Weighing the past and the future in decision making. European Journal of Cognitive Psychology, 17(4), 561-575. https://doi.org/10.1080/09541440440000159

Khan, N. A. (2001). The Political Economy of Decentralized Local Governance in Bangladesh: A Retrospect. Indian Journal of Social Work, 62(1), 90-105.

Khan, Z. R., \& Hussain, A. (2001). Review/Stocktaking in Local Governance. University of Dhaka.

Klingner, D. E. (1996). Public Personnel Management and Democratization: A View from Three Central American Republics. Public Administration Review, 56(4), 390-399. https://doi.org/10.2307/976381

Lawrence, P. R., \& Lorsch, J. W. (1967). Organization and Environment. Cambridge, MA: Harvard University Press.

Lindblom, C. E. (1959). The Science of "Muddling Through". Public Administration Review, 19(2), 79-88. https://doi.org/10.2307/973677

McGill, R. (1997). Civil service Reform in Developing Countries: A strategic Perspective from an Institutional Development Base. International Journal of Public Sector Management, 10(4), 254-267. https://doi.org/10.1108/09513559710180529

Menifield, C. E. (2013). The Basics of Public Budgeting and Financial Management, Second Edition. Lanham, Boulder, New York, Toronto and Polymouth: University Press of America.

Meyer, J. W., \& Rowan, B. (1977). Institutionalized organizations: Formal structure as myth and ceremony. American Journal of Sociology, 83, 340-363. https://doi.org/10.1086/226550

Organization for Economic Co-operation and Development (OECD). (1996). Ethics in the 
Public Service : Current Issues and Practices. Paris.

Ostrom, E., Schroeder, L., \& Wynne, S. (1993), Institutional Incentives and Sustainable Development, Boulder, CO: West view Press.

Oxhorn, P. (2004). Unraveling the Potential of Decentralization. In Decentralization, Democratic Governance, and Civil Society in Comparative Perspective (Oxhorn, P.). Washington, DC: Woodrow Wilson Center Press with Johns Hopkins University Press.

Pfeffer, J., \& Salancik, G. R. (1978). The External Control of Organizations: A Resource Dependence Perspective. New York: Harper \& Row.

Pfeffer, J., \& Salancik, G. R. (2003). The external control of organizations: A resource dependence perspective. California: Stanford University Press.

Prantilla, E. B. (Ed.). (1988). Financing Local and Regional Development in Developing Countries: Selected Country Experiences. Nagoya: UNCRD.

Rahman, S. H., Hossain, M. S., \& Uddin, M. M. (2016). Public Finance and Revenue Mobilization of Union Parishads: A Case of Four Union Parishads (BIGD Special Publication Series No.03. July 2016). Dhaka.

Rainey, H. G. (1997). Understanding and Managing Public Organizations. San Francisco: Jossey-Bass.

Rubin, I. S. (1990). Budget Theory and Budget Practice: How Good the Fit? Public Administration Review, 50(2). (Mar. - Apr., 1990), 179-189. https://doi.org/10.2307/976865

Rubin, I. S. (2014). The Politics of Public Budgeting - Getting and Spending, Borrowing and Balancing. Seventh Edition. Los Angeles, London, New Delhi, Singapore, Washington DC: Sage.

Schaeffer, M., \& Yilmaz, S. (2008). Strengthening Local Government Budgeting and Accountability. Policy Reserach Working 4767. https://doi.org/10.1596/1813-9450-4767

Selznick, P. (1949). TVA and the Grass Roots. Berkeley, CA: University of California Press.

Smith, R. W., \& Lynch, T. D. (2004). Public Budgeting in America. (5th, Ed.). Upper Saddle River, NJ: Pearson/Prentice Hall.

Smoke, P. (2003). Decentralization in Africa: Goals, Dimensions, Myths and Challenges. Public Administration and Development, 23(1), 7-16. https://doi.org/10.1002/pad.255

Stanovich, K. E., \& West, R. F. (2008). On the relative independence of thinking biases and cognitive ability. Journal of Personality and Social Psychology, 94(4), 672-695. https://doi.org/10.1037/0022-3514.94.4.672

Swift, A. (2014). Political Philosophy (Third). Cambridge and Malden: Polity Press.

Talukdar, M. R. I. (2009). Rural Local Government In Bangladesh. Dhaka: Osder 
Publications.

Talukdar, M. R. I. (2013). Rural Local Government In Bangladesh. Second Edition. Dhaka: Osder Publications.

Talukdar, M. R. I. (2014). Local Governance in Bangladesh - Policy and Strategy Framework, Dhaka: Osder Publications.

Talukdar, M. R. I. (2019). Influencing Phenomena of Local Government Union Councils' Budgeting Decisions in Bangladesh. A Ph.D. research-based article that is under consideration for publication by Commonwealth Journal of Local Governance.

Thompson, J. D. (1967). Organizations in Action. New York: McGraw-Hill.

Thoni, E. (1992). The Political Economy of Tax and Expenditure. In D. King (Ed.), Local Government Economics in Theory and Practice. London and New York: Routledge.

Thurmaier, K. M., \& Willoughby, K. G. (2001). Policy and Politics in State Budgeting. Armonk, NY: M.E. Sharpe.

United Cities of Local Government, (2011). The Local Government Finance: The Challenges of the 21 st Century. Cheltenham and Northampton: UCLG.

USAID Center for Democracy and Governance. (2000). Decentralization and Democratic Local Governance Programming Handbook. Washington, D.C.: USAID.

Wehner, J. (2015). Aaron Wildavsky, The Politics of the Budgetary Process. In M. et al. Lodge (Ed.), The Oxford Handbook of Classics in Public Policy and Administration. Oxford: Oxford University Press. https://doi.org/10.1093/oxfordhb/9780199646135.013.17

Westergaard, K. (2000). Decentralization in Bangladesh: Local government and NGOs, Center for Development Research, Copenhagen, Denmark; Paper prepared for presentation at the Colloquium on Decentralization and Development at Department of Political Science.

Wildavsky, A. (1964). The Politics of the Budgetary Process. Boston.

Williamson, O. E. (1975). Markets and Hierarchies: Analysis and Antitrust Implications. New York: Free Press.

Williamson, O. E. (1975). Markets and Hierarchies: Analysis and Antitrust Implications. New York: Free Press.

Zald, M. N. (1970). Organizational Change: The Political Economy of the YMCA. Chicago: University of Chicago Press. 


\section{Acknowledgement}

This is one of the articles developed based on my Ph.D. research. I acknowledge the review and guidance contribution of the Ph.D. advisors Dr. Achakorn Wongpreedee, Associate Professor of Graduate School of Public Administration (GSPA)-National Institute of Development Administration (NIDA), and Dr. Tatchalerm Sudhipongpracha, Associate Professor of Thammasat University. I also admit the extensive contribution of the Ph.D. dissertation seminar instructor Dr. Boon-Anan Phinaitrup, Associate Professor and Dean of GSPA-NIDA, Bangkok.

\section{Copyright Disclaimer}

Copyright for this article is retained by the author, with first publication rights granted to the journal. This is an open-access article distributed under the terms and conditions of the Creative Commons Attribution license (http://creativecommons.org/licenses/by/4.0/). 